\title{
ENSO Forecasts near the Spring Predictability Barrier and Possible Reasons for the Recently Reduced Predictability
}

\author{
ANDY WANG-CHUN LAI \\ Centre for Atmospheric Science, University of Cambridge, Cambridge, United Kingdom, and \\ Hong Kong Observatory, Hong Kong, China \\ Michael Herzog AND HANS-F. GRAF \\ Centre for Atmospheric Science, University of Cambridge, Cambridge, United Kingdom
}

(Manuscript received 20 March 2017, in final form 1 September 2017)

\begin{abstract}
A cross-validated statistical model has been developed to produce hindcasts for the 1980-2016 NovemberDecember-January (NDJ; assumed El Niño peak) mean Niño-3.4 sea surface temperature anomalies (SSTA). A linear combination of two parameters is sufficient to successfully predict the peak SSTA: 1) the $5^{\circ} \mathrm{N}-5^{\circ} \mathrm{S}, 130^{\circ} \mathrm{E}-180^{\circ}, 5-250-\mathrm{m}$ oceanic potential temperature anomalies in February and 2 ) the $5^{\circ} \mathrm{N}-5^{\circ} \mathrm{S}$, $140^{\circ} \mathrm{E}-160^{\circ} \mathrm{W}$ cumulative zonal wind anomalies (ZWA), integrated from November (one year before) up to the prediction month. This model is simple but is comparable to, or even outperforms, many NOAA Climate Prediction Center's statistical models during the boreal spring predictability barrier. In contrast to most statistical models, the predictand Niño-3.4 SSTA is not used as a predictor. The explained variance between observed and predicted NDJ Niño-3.4 SSTA at a lead time of 8 months is $57 \%$ using $5 \mathrm{yr}$ for cross validation and $63 \%$ in full hindcast mode.Predictive skill is lower after 2000 when the mean climate state is more La Niña-like because of stronger equatorial easterly ZWA. Strengthened Pacific subtropical highs are observed, with weaker westerly ZWA that emerge at a later time during El Niño. The western Pacific is more recharged, with stronger upwelling over the eastern Pacific. The resulting strong zonal subsurface temperature gradient provides a high potential for Kelvin waves being triggered without strong westerly ZWA. However, the persistent easterly ZWA lead to more central Pacific-like El Niños. These are more difficult to predict because the contribution of the thermocline feedback is reduced. Overall, the authors find that the importance of the recharge state for ENSO prediction has increased after 2000, contradicting some previous studies.
\end{abstract}

\section{Introduction}

El Niño-Southern Oscillation (ENSO) is one of the most important interannual fluctuations of the climate system. ENSO affects many parts of the globe through teleconnections and influences Pacific marine ecosystems and commercial fisheries (e.g., Kiladis and Diaz 1989; Ropelewski and Halpert 1987). Hence, ENSO prediction is of considerable public interest. Predictions are based on either dynamical or statistical models. For ENSO predictions, dynamical models solve physical equations of the ocean-atmosphere system ranging from relatively simple to complex fully coupled oceanatmosphere models. The fully coupled models perform slightly better than statistical models (Latif et al. 1994;

Corresponding author: Michael Herzog, mh526@cam.ac.uk
Barnston et al. 2012). Their higher forecasting skill is due to higher spatial resolution and advanced data assimilation systems for initialization (Balmaseda and Anderson 2009). The expense of running these models often limits the number and frequency of forecasts conducted (Goddard et al. 2001). Statistical models, on the other hand, use long historical datasets to estimate their predictor-predictand relationships. They are much cheaper, and the use of longer historical data and finer temporal resolution often leads to better forecasts (Barnston et al. 2012).

Both types of models have problems in predicting boreal winter tropical Pacific sea surface temperature (SST) when forecasts start in boreal spring (FebruaryMay). This is called the spring predictability barrier (e.g., Flügel and Chang 1998; Jin et al. 2008). The ENSO SST anomalies (SSTA) and associated sea level pressure 
anomalies are weakest during spring, but the noise in the tropical Pacific air-sea system is nearly constant throughout the year (Xue et al. 1994). Hence, the signalto-noise ratio is small in boreal spring and forecasts are more sensitive to random variability. In addition, during spring the intertropical convergence zone is situated close to the equator and the climatological SST reaches its maximum in the eastern equatorial Pacific. This leads to unstable air-sea interactions in the eastern equatorial Pacific, whereby the release of latent heat by the ocean alters surface winds, further inducing latent heat release (Philander et al. 1984). Since zonal SST gradients are weak during spring, small perturbations can be amplified over a large domain, leading to very different spatial patterns (Latif et al. 1994). Springtime also sees more ENSO events in the decaying phase because ENSO is seasonally phase locked with peaks usually during boreal winter (Torrence and Webster 1998). The decaying phase implies that the SSTA in boreal spring are relatively small, making SSTA associated with ENSO more difficult to detect and forecast accurately, leading to a minimum predictability in spring (Jin et al. 2008).

The explained variance $R^{2}$ between observed SSTA and forecasts made in spring for the following winter Niño-3.4 SST ranges from $1 \%$ to $24 \%$ for statistical models and from $4 \%$ to $64 \%$ for dynamical models (Barnston et al. 2012). In this study, we present a new simple statistical model that performs as well as some of the best dynamical models and outperforms most of the statistical models during the period around the spring predictability barrier. Our model is conceptually similar to Clarke and Van Gorder (2003) but avoids using past information about the predicted SSTA in the forecast method. In the following, we present all forecasting skill in terms of explained variance $R^{2}$; a stricter measure of the strength of the predictor-predictand relationship than the correlation coefficient $R$.

Some studies have suggested that El Niño (EN) can occur in two different flavors: the warm pool or central Pacific (CP) El Niño (CPEN) and the canonical eastern Pacific (EP) El Niño (EPEN) (Graf 1986; Ashok et al. 2007; Kao and Yu 2009; Kug et al. 2009; Yu and Kim 2010). Although not the primary focus of this study, CP and EP La Niña (LN) patterns have also been identified (Lee and McPhaden 2010). Whether EN can be classified discretely into these two types is still a matter of debate. More recent studies have shown that EN is a continuum, with CPEN and EPEN as the end members of the spectrum (Giese and Ray 2011; Johnson 2013; Fedorov et al. 2015; Chen et al. 2015; Lai et al. 2015). Also, as Graf (1986) suggested and Lai et al. (2015) have shown, El Niño is a two-stage process. All ENs start as CP and, depending on the involvement of the thermocline feedback, can develop into more or less strong EP events (Graf 1986; Lai et al. 2015). Most ENs are hybrid events, with both CPEN and EPEN characteristics, that do not evolve into very strong events. The variability of the November-December-January (NDJ) EN peak intensity, and therefore the diversity of EN events, depends strongly on the initial west Pacific thermocline recharged state and on the western to central equatorial Pacific cumulative zonal surface wind anomalies (ZWA) (Lai et al. 2015). Our model will only use these two parameters to predict the Niño3.4 SSTA at lead times (LTs) extending to 9 months (i.e., across the spring predictability barrier).

Often ENSO forecast methods use not only precursors within the tropical Pacific basin, but also external forcings. In this sense, several authors have relied on the importance of the SSTs in other tropical basins to predict ENSO events. Dayan et al. (2014) have reported an enhancement of ENSO prediction skill associated with diverse SST patterns in the tropical Atlantic and Indian basins. Furthermore, Frauen and Dommenget (2012) have explored the contribution of each basin, putting forward that Indian Ocean SSTs are necessary to the correct simulation of ENSO dynamics, while the initial conditions of the tropical Atlantic SSTs are crucial for ENSO predictability.

Recent studies have focused on the role of tropical Atlantic interannual variability for the tropical Pacific. In this sense, Keenlyside et al. (2013) found an improvement of ENSO prediction across boreal spring when the Atlantic SSTs are included. Nevertheless, the Atlantic impact on ENSO seems to be modulated at decadal time scales. Martín-Rey et al. (2015) demonstrated the existence of windows of opportunity to enhance ENSO prediction using the information from the Atlantic six months in advance. Only during the first and last decades of the twentieth century, when the Atlantic-Pacific Niños connection takes place (Rodríguez-Fonseca et al. 2009; Ding et al. 2012; Martín-Rey et al. 2014; Polo et al. 2015), a good prediction skill is obtained. Therefore, Suárez-Moreno and Rodríguez-Fonseca (2015) developed a statistical model taking into account the nonstationary behavior of the climate teleconnections between tropical oceans. However, as McGregor et al. (2014) showed, these teleconnections and their influence on ENSO are mediated through a response in the Walker circulation and a change in zonal surface wind anomalies.

In addition, there is evidence that these teleconnections between tropical oceans also favor certain types of EN. For instance, SST anomalies in the north tropical Atlantic during boreal spring could entail an atmospheric response over the central-eastern tropical Pacific modifying the surface winds and favoring the CPEN development 
(Ham et al. 2013a; Wang et al. 2017). Moreover, equatorial Atlantic SSTs (i.e., Atlantic Niño) could also alter the Walker circulation, impacting on the surface winds in the central-western Pacific, and trigger oceanic Kelvin waves (Rodríguez-Fonseca et al. 2009; Ham et al. 2013b; Polo et al. 2015; Li et al. 2016).

Stratospheric volcanic eruptions are another example of externally forced events that influence ENSO (Adams et al. 2003). As a recent modeling study has shown, volcanic cooling for tropical eruptions is stronger in the high latitudes, leading to an enhanced equator-topole temperature gradient and tending to accelerate the westerlies while enhancing baroclinic instability closer to the equator (Stevenson et al. 2016).

In summary, although there are many causes of westerly wind anomalies, the simplest method to include these causes in a statistical method for ENSO prediction is through the resulting westerly wind anomalies and through indicators of the original cause of these wind anomalies itself.

ENSO predictability has dropped for recent years. Barnston et al. (2012) analyzed the seasonal forecast skill of many dynamical and statistical models for the most recent decade. This study shows that forecasting ENSO posed a greater predictive challenge after the early 2000s. Reasons are not entirely clear, but this study suggests that it could be related to a smaller ENSO amplitude and greater year-to-year fluctuations between El Niño and La Niña. McPhaden (2003) proposed that the warm water volume [i.e., the mean upper-ocean heat content (OHC) of the $120^{\circ} \mathrm{E}-80^{\circ} \mathrm{W}$ equatorial Pacific] is often a good predictor for ENSO seasonal forecasting, since lag correlations are greater than 0.7 at lead times of 7-9 months for anomalies starting in February through May. However, several recent studies have pointed out that the equatorial Pacific $\mathrm{OHC}$ has a weaker correlation with the Niño-3.4 region since 2000 (Horii et al. 2012; McPhaden 2012). In addition, there has been a westward displacement of the anomalous wind forcing associated with ENSO after 1999 (Bunge and Clarke 2014).

As noted in many studies, the Pacific has undergone a climate regime shift in the late 1990s after the strong 1997/ 98 EPEN (Minobe 2000; Bond et al. 2003; Hong et al. 2014). This shift is characterized by a warming of the west Pacific (WP) and a cooling of the CP. Such a shift may explain the breakdown of the $\mathrm{OHC}$ as one of the ENSO predictors after 2000 (Horii et al. 2012; McPhaden 2012; Bunge and Clarke 2014). The reduced predictability of ENSO might also be due to the recent El Niño shift to a more CPEN flavor, in which the SST warming is not related to a thermocline feedback (Chung and Li 2013; Xiang et al. 2013; Lai et al. 2015). Possible causes can be related to natural ENSO variability on interdecadal time scales (Chen and Wallace 2015). This includes subtropical and extratropical signatures in SST, such as the Pacific decadal oscillation (PDO) pattern (Pascolini-Campbell et al. 2015). Hu et al. (2013) found that the interannual thermocline variability has decreased for 2000-11, citing a stronger Walker circulation as a possible cause. Conversely, Sohn et al. (2013) suggested that a decadal variation of El Niño (more CPEN) caused the Walker circulation to intensify. Wen et al. (2014) also support the view that the basinwide mean thermocline variation is not a good predictor for El Niño after 1999. They proposed that strengthened subtropical cells provide a pathway for the enhanced influence of off-equatorial thermocline variations on the development of ENSO events after 1999. Lyon et al. (2014) found that after removing the effects of ENSO and global warming from the data, the climate regime shift around 1999-2000 could result from a change in the PDO phase, but the causality between the two was not addressed.

Besides the PDO, other large-scale decadal SST patterns such as the Atlantic multidecadal oscillation (AMO) could also contribute to the observed regime shift. Several authors have proposed that AMO-like SST patterns could modify the tropical Pacific background state and ENSO seasonal cycle, enhancing-reducing ENSO variance (Dong et al. 2006; Timmermann et al. 2007; Zhang and Delworth 2005; Zanchettin et al. 2016; Levine et al. 2017). Another factor could be global warming, which could interact with the natural internal variability to generate the ENSO variations during recent decades (Kucharski et al. 2011; Kang et al. 2014; Liu and Sui 2014).

Xiang et al. (2013) point out that the more La Niñalike ocean state after 1999 caused an anomalous subsidence in the $\mathrm{CP}$, displacing the weak westerlies to the west. This, together with anomalous easterlies in the EP, restricts the SST anomalies to the central part of the basin, favoring a CPEN development. The La Niña-like mean state after 1999 could also favor the occurrence of negative ENSO events, since the ENSO asymmetry seems to be attributed to zonal displacement of the surface winds and the wind-SST feedback (Kang and Kug 2002; Frauen and Dommenget 2010). Furthermore, the ENSO phase, together with its flavor (CP and EP spatial configurations), seems to be crucial to determine its characteristics and teleconnections (Dommenget et al. 2013; López-Parages et al. 2016).

In this paper, we update, augment, and refocus the analysis of the change in mean climate state that has led to a change in forecast performances.

The paper is structured as follows. In section 2 we describe our new simple statistical model for ENSO forecasts. Model validation and performance are presented in 
section 3a. Observational evidence for recent changes in the key parameter of our model is presented in section $3 \mathrm{~b}$. Potential mechanisms for a reduced forecast skill after the year 2000 are discussed in section 4. Conclusions and outlook follow in section 5 .

\section{Statistical model for ENSO prediction}

The LT is defined by the number of months of separation between the forecast and the central month of the 3-month target (i.e., December for NDJ). For example, using observed data from the months up to and including June represents a lead time of 5 months for a NDJ prediction. The notations (-1), (0), and (1) attached to each month indicate the year before, during, and after the El Niño occurrence, respectively. The peak of an El Niño is assumed to be November(0)-December(0)January(1), or NDJ hereafter.

The National Oceanic and Atmospheric Administration (NOAA) definition of El Niño is adopted. As described in Lai et al. (2015), an El Niño (La Niña) event starts when the monthly mean SSTA exceeds (is below) $0.5 \mathrm{~K}$ for at least 6 consecutive months anywhere between $160^{\circ} \mathrm{E}$ and $80^{\circ} \mathrm{W}$ along the $5^{\circ} \mathrm{N}-5^{\circ} \mathrm{S}$ equatorial band. The onset month is the first of the 6 consecutive months. During an El Niño event, a monthly SSTA pattern is considered to be a CP warming pattern if regions of SSTA with $1.0 \mathrm{~K}$ or above do not reach the coast of Peru (i.e., do not reach the Niño-1 or Niño-2 region). The threshold of $1.0 \mathrm{~K}$ is chosen because a $0.5-\mathrm{K}$ threshold (used for defining onset and end of the ENSO episode) is not sufficiently high to distinguish the spatial differences between CPEN and EPEN, due to the high noise of SSTA in this region. For an EP SSTA pattern SSTA exceed $1.0 \mathrm{~K}$ near the coast of Peru (in either Niño-1 or Niño-2). An El Niño event is considered to be a CPEN event if only a CP warming pattern occurs during its evolution. It is considered an EPEN event if more months are characterized by an EP than a CP pattern over the lifetime of the event. Mixed CP and EP patterns occurring over the lifetime simultaneously or subsequently are called hybrid El Niño events (HBEN).

Since our statistical model is motivated by west wind anomalies as a trigger for Kelvin waves, we focus in the discussions on El Niño events. However, all years including neutral and La Niña years are included in the analysis so that the model is optimized for all years, not just El Niño years.

In our model, an expected peak in Niño-3.4 SSTA during NDJ $\left\langle T_{\text {peak }}\right\rangle$ is calculated using a linear relationship between two parameters obtained from the NOAA 1980-2014 reanalysis (Reynolds et al. 2002; Compo et al. 2011) and the Global Ocean Data Assimilation System
(Behringer and Xue 2004): the cumulative $5^{\circ} \mathrm{N}-5^{\circ} \mathrm{S}$, $140^{\circ} \mathrm{E}-160^{\circ} \mathrm{W}$ ZWA, $\Delta U$, starting in November $(-1)$ and cumulated to the month $t$ in which the prediction is made, and the February $(0) 5^{\circ} \mathrm{N}-5^{\circ} \mathrm{S}, 130^{\circ} \mathrm{E}-180^{\circ}, 5-250-\mathrm{m}$ oceanic subsurface potential temperature anomalies (PTA) $\Delta \theta$ :

$$
\left\langle T_{\text {peak }}\right\rangle=\alpha(t) \frac{\Delta \theta}{\bar{\theta}}-\beta(t) \frac{1}{\bar{U}} \sum_{i=\operatorname{Nov}(-1)}^{t} \Delta U(i) .
$$

The $\bar{\theta}$ and $\bar{U}$ are the climatological means of oceanic subsurface potential temperature and zonal wind for the same domain as for $\Delta \theta$ and $\Delta U$, respectively. The minus sign in front of coefficient $\beta$ ensures positive values of $\beta$ for westerly wind anomalies $(\Delta U>0)$ and easterly mean zonal wind $(\bar{U}>0)$.

Note that the upper-ocean heat content can also be estimated by other parameters (e.g., Meinen and McPhaden 2000; Fedorov et al. 2015). The calculation for $\left\langle T_{\text {peak }}\right\rangle$ was repeated for each year from 1980 to 2016 and for each month starting from February (9-month lead time). The computation of $\left\langle T_{\text {peak }}\right\rangle$ is also applied to LN events and neutral years, as it is meant to represent the NDJ Niño-3.4 SSTA for all years and not just for warm events.

The PTA and ZWA are normalized by their climatological means to describe effects through relative deviations so that the coefficients $\alpha$ and $\beta$ both have units of temperature. The $\beta \times \Sigma \Delta U / \bar{U}$ describes the combined effects of thermocline feedback, zonal advection, and heat flux due to zonal wind forcing on SST. The values of $\alpha$ and $\beta$ are listed in Fig. 1. They are determined, for each lead time, by a least squares fitting over the training period so that $R^{2}$ of the relationship between predicted $\left\langle T_{\text {peak }}\right\rangle$ and the observed $T_{\text {peak }}$ for a given $t$ is maximized. ZWA from the European Centre for Medium-Range Weather Forecasts (ECMWF) interim reanalysis (ERAInterim) data produced very similar results (not shown) compared to the NOAA based ZWA data.

We tested the $R^{2}$ for different times of the PTA around boreal spring. The Feb(0) PTA lead was found to be the optimal choice. This is consistent with McPhaden (2003), who found a maximum lag correlation for the equatorial Pacific warm water volume (WWV) at lead times of 9 months in February. In addition, several domain sizes for averaging the PTA and for cumulating the ZWA around the WP-CP were also tested. The chosen domains for PTA and ZWA result in the highest $R^{2}$. Restricting PTA to the WP deviates from McPhaden (2003), who proposed the use of warm water volume (WWV) across the entire equatorial Pacific to overcome the spring predictability barrier. However, WWV is not a good predictor after the 2000 Pacific 

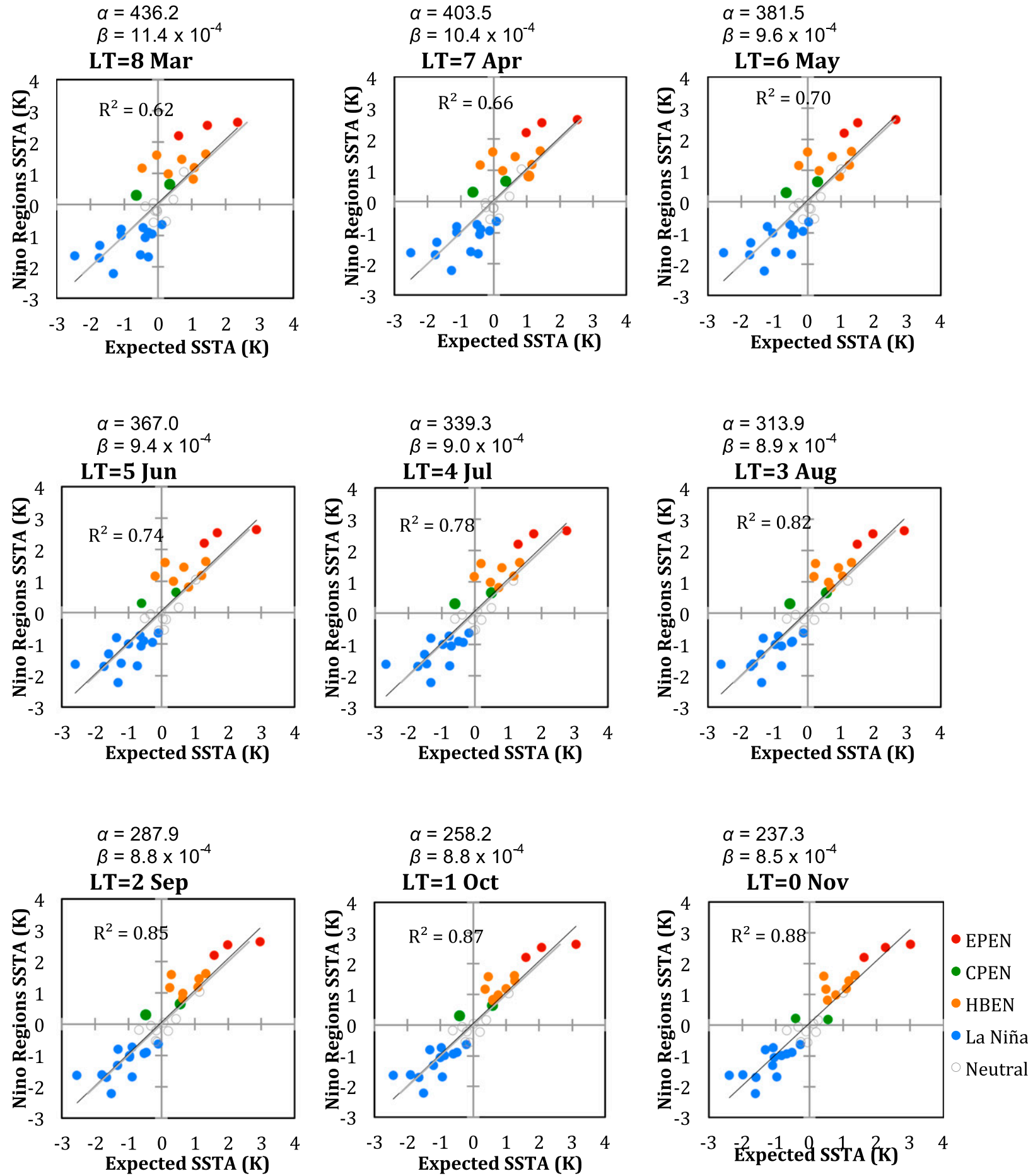

FIG. 1. Scatterplots of the observed Niño-3.4 SSTA in NDJ against the expected NDJ SSTA from our model during the period 19802016. The LT in months and the coefficients $(\alpha$ and $\beta)$ that maximized $R^{2}$ and $R^{2}$ are shown on top of each plot. Plot for LT $=9$ is not shown. The 1:1 line is marked in gray.

climate regime shift (Bunge and Clarke 2014). Averaged over the whole equatorial Pacific, negative PTA in the east tend to cancel positive PTA in the west after 2000. Our model is built based on the physical mechanisms described in Lai et al. (2015). Much in line with Wyrtki (1975) and Graf (1986), this study suggests that the WP recharged state during boreal spring can force positive EP SSTA through the thermocline feedback. Once the 
TABLE 1. Models whose forecasts for Niño-3.4 SSTA are included in this study. Hindcasts are provided by the authors, the stated websites, or people in the acknowledgment section.

\begin{tabular}{|c|c|c|}
\hline Acronyms & Full name & Authors \\
\hline $\mathrm{CPC}$ & Climate Prediction Center & \\
\hline CPC LIM & Linear inverse model & Penland and Magorian (1993) \\
\hline CPC CA & Constructed analog & Van den Dool (1994) \\
\hline CPC MRKOV & Markov model & Xue et al. (1994) \\
\hline CPC CCA & Canonical correlation analysis & Barnston and Ropelewski (1992) \\
\hline FSU & $\begin{array}{l}\text { Florida State University, } \\
\text { multiple regression }\end{array}$ & Clarke and Van Gorder (2003) \\
\hline NASA GMAO & $\begin{array}{l}\text { Global Modeling and } \\
\text { Assimilation Office }\end{array}$ & http://iridl.ldeo.columbia.edu/SOURCES/.Models/.NMME/ \\
\hline NOAA CFS & $\begin{array}{l}\text { Climate Forecast System, } \\
\text { version } 2\end{array}$ & Saha et al. (2014); http://iridl.ldeo.columbia.edu/SOURCES/.Models/.NMME/ \\
\hline
\end{tabular}

WP is recharged, sustained strong westerly wind anomalies over the WP and CP can trigger eastwardpropagating Kelvin waves from the WP recharged region and cause a full-fledged EPEN. This results in higher SSTA compared to those associated with a CPEN, which are caused by zonal advection feedback and local air-sea interaction, mainly through the exchange of latent and sensible heat. Lai et al. (2015) found that the WP recharged state and cumulative zonal wind anomalies can explain about $70 \%$ of the total variance in the SSTA Niño-3.4. We therefore propose that WP recharged state is a better predictor than taking into account the entire equatorial Pacific, which would include signals over the EP induced by the climate regime shift. The opposite changes in $\mathrm{OHC}$ for WP and EP would mask changes in the WP recharge state if the $\mathrm{OHC}$ of the entire equatorial Pacific was used as a predictor. Note that the optimal time and area for the calculation of PTA and ZWA may change when the base state of the Pacific climate system changes.

We compare our model results with other statistical models and two dynamical models. Results for the statistical models were obtained from the original authors. These include the NOAA Climate Prediction Center's (CPC) linear inverse model (LIM) by Penland and Magorian (1993), CPC constructed analog (CA) by Van den Dool (1994), CPC Markov model by Xue et al. (1994), CPC canonical correlation analysis (CCA) by Barnston and Ropelewski (1992), and the Florida State University's multiple regression model (FSU) by Clarke and Van Gorder (2003). Results for the dynamical models are obtained from the International Research Institute Data Library website for the NASA Global Modeling and Assimilation Office (GMAO) and the NOAA Climate Forecast System, version 2 (CFS). Information about the models is summarized in Table 1.

It is inevitable that each model has different training, verification, and validation periods. FSU is trained using
1981-2001, so that hindcasts for this time period are not cross validated. CA uses $1956-2015$ as its crossvalidation period and is trained using 1982-95 with a 1996-2006 verification period. Hindcasts are then reproduced for 1980-2007. For later years, CCA uses an adaptive regression so that new predictions are based on the most recently available data. Markov is trained using 1980-95 and built with three multivariate EOFs in which the anomalous fields of SST, sea level, and wind stress are equally weighted. LIM is trained using $1950-84$ and then verified using 1985-90. For all models, forecasts are made up to 2014 in operational mode after verification and cross validation. Cross validation is performed for those years that are excluded from the training of the model.

Because of these differences in verification and validation, the comparison with other models might favor our model. However, instead of showing whether our model is the best or not, we want to emphasize the simplicity of our model. Derived from a simple theoretical framework, it works at least as well as more complex models. To test overfitting of our model, we applied a Monte Carlo method to validate the model, as suggested by DelSole and Shukla (2009). The choice of parameters for predictions is based on a physical mechanism and optimized by explained variance as explored in Lai et al. (2015). Our model is calibrated using all years between 1980 and 2016. For validation, the 37 years of data are partitioned into two subsets of 32- and 5 -yr samples, similar to Newman et al. (2011). The $\alpha$ and $\beta$ are then computed for the target season of NDJ through a linear least squares fitting, taking into account only data from the 32-yr sample. The remaining $5 \mathrm{yr}$ (not included in the least squares fit) are then used for validation. Subsets are chosen by a Monte Carlo random sampling method and repeated 70 times. Validation results are already converged after approximately 50 repetitions. A one-year cross validation [e.g., as done in 
Clarke and Van Gorder (2003)] yields very similar $R^{2}$ compared with the mean $R^{2}$ from the 5-yr cross validation, indicating that the methods are robust (not shown). To investigate the drop in forecast skill after 2000, we present $R^{2}$ for the subperiods $1980-99$ and 2000-16.

To assess the performance of the cross-validation method we not only compare mean and median values of the individual $R^{2}$ of the 70 repetitions but also use the Akaike information criteria (AIC; Burnham and Anderson 2002) to calculate optimal coefficients $\alpha_{\text {best }}=\sum_{j=1}^{N} w_{j} \alpha_{j}$ and $\beta_{\text {best }}=\sum_{j=1}^{N} w_{j} \beta_{j}$, where $N=70$ is the number and $\alpha_{j}$ and $\beta_{j}$ are the coefficients of each cross-validation calculation. The weighting factors $w_{j}$ are estimated from the AIC values the individual crossvalidation calculations:

$$
\begin{aligned}
w_{i} & =\frac{\exp \left(-0.5 \Delta_{i}\right)}{\sum_{j=1}^{N} \exp \left(-0.5 \Delta_{j}\right)}, \\
\Delta_{i} & =\mathrm{AIC}_{i}-\mathrm{AIC}_{\text {min }}, \quad \text { and } \\
\mathrm{AIC} & =n \ln \left(\frac{\mathrm{RSS}}{n}\right)+2 K+\frac{2 K(K+1)}{n-K-1} .
\end{aligned}
$$

RSS is the sum of squares of differences between predicted and actual $\left\langle T_{\text {peak }}\right\rangle, K=2$ is the number of coefficients in our model, $n=5$ the number of years used to test the model in each cross-validation calculation, and $\mathrm{AIC}_{\min }=\min _{j} \mathrm{AIC}_{j}$.

\section{Results}

\section{a. Model validation and performance}

During the 1980-2016 period, including the 2015/16 El Niño event, there are $12 \mathrm{El}$ Niños and 12 LNs. Figure 1 shows scatterplots of observed NDJ Niño-3.4 SSTA and predicted $\left\langle T_{\text {peak }}\right\rangle$ for each LT. The offset of the best-fit linear regression lines is negligible. Different flavors of the El Niño continuum, CPEN, EPEN, and hybrid (Lai et al. 2015), are shown in green, red, and orange, respectively. Neutral years are gray open circles. LNs are in blue.

Initially, forecasts tend to underestimate the SSTA for El Niño (i.e., dots for El Niño are mostly above the main diagonal in Fig. 1). Although the ocean signal (PTA) is strongest during the boreal spring recharged state, the influence of the atmospheric signal (westerly ZWA) increases over time. As time progresses, more information is available to predict an El Niño event. Forecasts improve from LT $=8$ up to LT $=0$ as indicated by the convergence of the data points toward the regression lines. Almost all data points are in the correct quadrant, except for the weak 2003/04 CPEN, which is predicted to be a cold event throughout. Although the main focus was not to predict $\mathrm{LN}$, all predicted $\mathrm{LN}$ events gradually shift to the "cold" bottom left quadrant. This indicates that there is no false prediction for $\mathrm{LN}$ events starting from $\mathrm{LT}=5$. Even though the model's domain might capture a strong positive PTA prior to $\mathrm{LN}$, the effect of strong easterly ZWA that generate strong oceanic upwelling throughout the seasons leading to an LN is typically well captured by the model.

Figure 2a shows the range of $R^{2}$ for each LT obtained from the 70 sets of 5-yr validations. The bottom and top of the whiskers indicate the minimum and maximum $R^{2}$, respectively. The bottom of the box, the line inside the box, and the top of the box indicate the 25th percentile, median, and 75th percentile, respectively. The range of $R^{2}$ as seen in the whisker plot is wide because the $R^{2}$ for observed and predicted $\left\langle T_{\text {peak }}\right\rangle$ is sensitive to the specific control and validation sample. For example, for $\mathrm{LT}=8$, $R^{2}$ ranges from $0 \%$ to $92 \%$, whereas 25 th to 75 th percentiles are between $42 \%$ and $83 \%$ explained variance with a mean and median of $58 \%$ and $63 \%$, respectively. Very low $R^{2}$ are inevitable because the randomly selected $5 \mathrm{yr}$ sometimes include years with considerable forecasting challenges. However, overall, the $R^{2}$ distributions are negatively skewed toward the lower values. Median values are larger than mean values as seen by the whisker boxes. The optimal model from the AIC method has $\alpha$ and $\beta$ coefficients that are almost identical to the coefficients of the full hindcast model. Thus, the $R^{2}$ for the optimal coefficients from the cross-validation method is only $2 \%$ smaller than from a full hindcast. Figure $2 \mathrm{~b}$ indicates that our model performs well for ENSO prediction during the spring forecast barrier for $\mathrm{LT}=9$ to 6 (black solid line). For LT $=6$ and 7, only NOAA CFS and CPC CA are better. Unfortunately, predictions for $\mathrm{LT}=8$ and 9 are not available for the NOAA CFS model. NOAA CFS has the best skill in terms of $R^{2}$, which is about $10 \%$ higher than our model from LT $=6$ to 0 . The FSU model, which uses similar parameters compared to our model, does not perform better until $\mathrm{LT}=2$. FSU uses Indo-Pacific wind stress anomalies and upper-ocean heat content, with a longitudinal domain at which the wind stress anomalies are obtained shifting from the east to the west during the course of the year. In addition, it includes the Niño-3.4 SSTA of the month from which the forecast is being made (Clarke and Van Gorder 2003). Thus, FSU includes observational information of the predictand, leading naturally to high forecast skill at short LT. Our statistical forecast model avoids such an inclusion of the predictand in the forecast method, since the main signal of the ENSO evolution is below the ocean surface at 


\section{(a) Cross-validated $R^{2}$ for $1980-2016$}
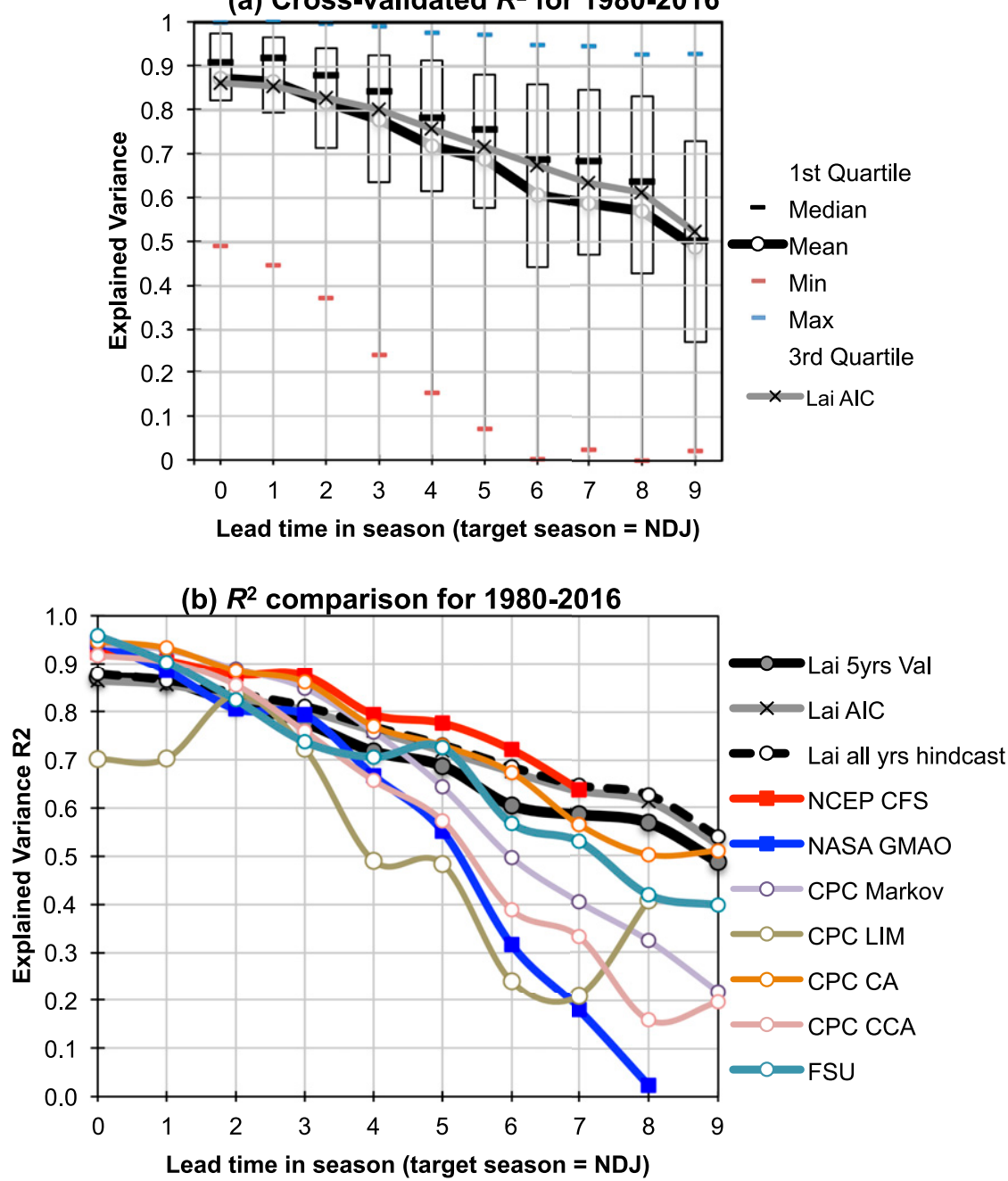

FIG. 2. (a) The whisker plots of $R^{2}$ when our model is cross validated using 70 sets of Monte Carlo randomly selected 5-yr samples. The black line shows the mean $R^{2}$ of the 70 sets and the gray line the $R^{2}$ of the AIC optimized model as described in the text. The whiskers from bottom to top show the minimum, 25 th percentile, median, 75 th percentile, and maximum. (b) Temporal $R^{2}$ between model forecasts and observed NDJ Niño-3.4 SSTA as a function of lead times. The black line shows the mean $R^{2}$ for our model from the 5-yr cross validation, the gray line the $R^{2}$ of the AIC optimized model. The black dashed line is for the 1980-2016 hindcast.

long LT, not in the SST (Lai et al. 2015). CPC CA can be regarded as the best statistical model, which performs better than ours from LT $=6$ to 0 and is comparable to our model at $\mathrm{LT}=7,8$, and 9. Interestingly, NASA GMAO has lower skill until LT $=3$. Most models have about $5 \%$ higher explained variance than our model at very short lead times LT $=2$ to 0 . For comparison, we have added in Fig. $2 b$ the explained variance of our model in full hindcast mode as a black dashed line. The $R^{2}$ is approximately $10 \%$ higher for LT $>3$ when all available data are included in the best fit calculation. To test the hypothesis that the strongest EPEN might have a dominant effect on the regression results, we removed the 1982/83 and 1997/98 EPEN from the analysis. Even with both these EPEN removed $R^{2}$ values are reduced by no more than 0.1 (i.e., $10 \%$ ) even for the longest lead times.

It is worth noting that all other statistical models include the observed SSTA in their SSTA prediction. When making a prediction in November for NDJ $(\mathrm{LT}=1)$, the observed November SSTA is already used for the prediction. Our model does not directly use SSTA. It is 
(a) Cross-validated $R^{2}$ for $1980-1999$

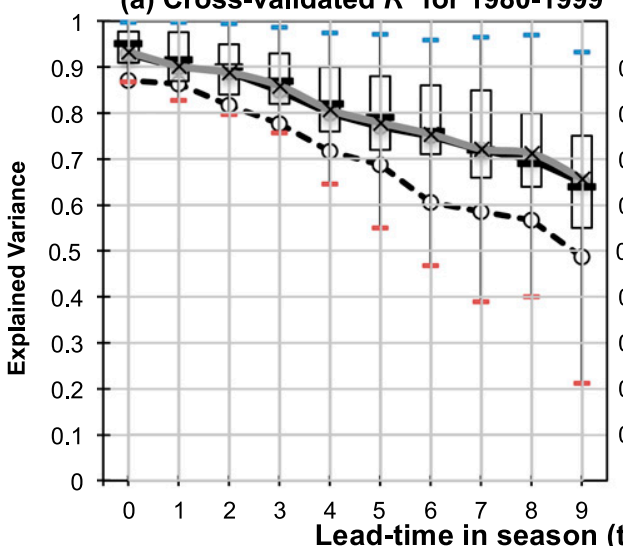

(b) Cross-validated $R^{2}$ for $\mathbf{2 0 0 0 - 2 0 1 6}$

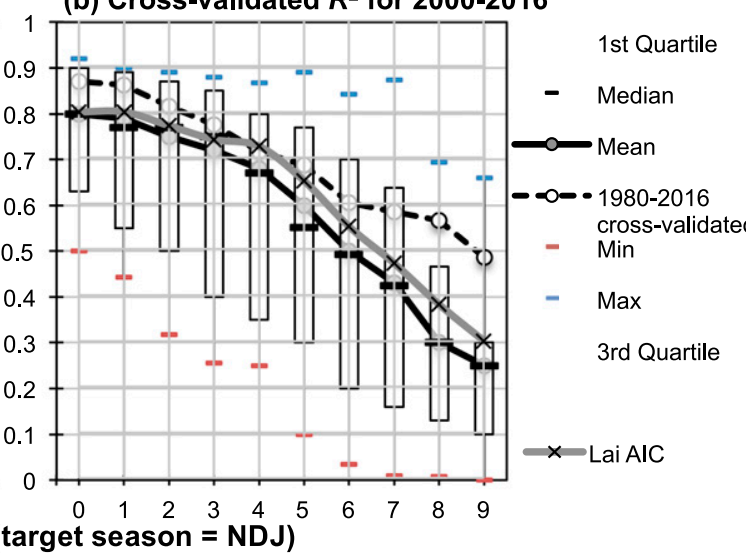

(c) $R^{2}$ comparison for $1980-1999$

(d) $R^{2}$ comparison for $2000-2016$
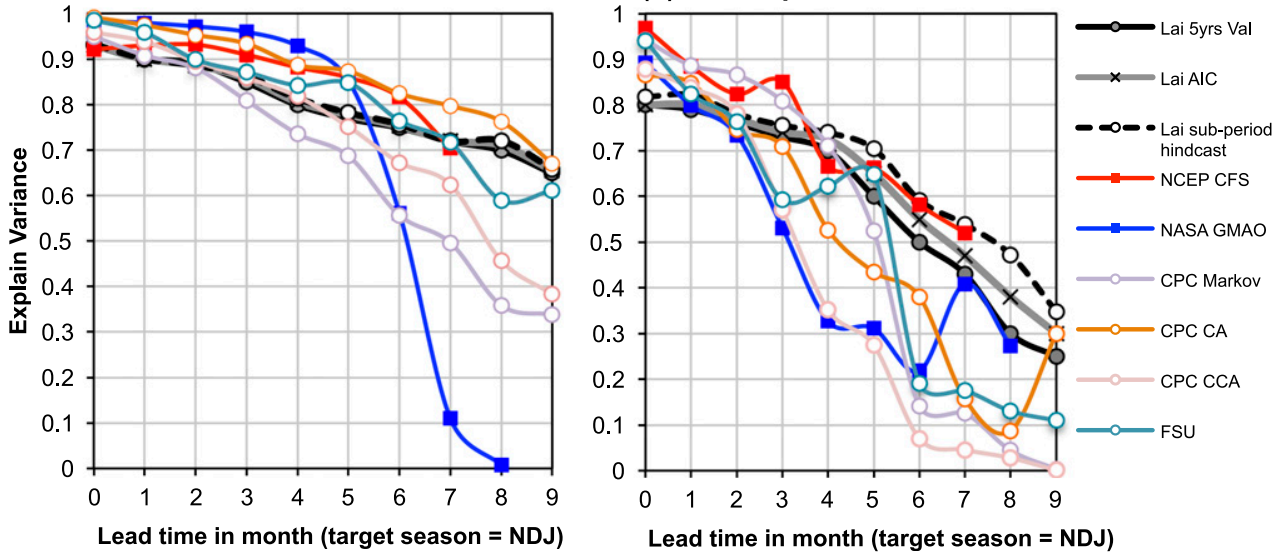

FIG. 3. (a),(b) As in Fig. 2a, where 5 yr from the subperiod of 1980-99 and 2000-16, respectively, are left out from the calibration and then used for validation, resulting in the whiskers and mean (black line). The black dashed line shows the mean $R^{2}$ of subperiod hindcast and the gray line the $R^{2}$ from the AIC optimized model. (c),(d) As in Fig. 2b, but only for the subperiods, with black dashed and gray lines as in (a) and (b), respectively.

only based on the western Pacific PTA of February and the cumulative ZWA. The predictand (SSTA, the observed variable of interest) might, however, implicitly contribute to the values of zonal wind anomalies through its influence on Walker and Hadley cells (Bjerknes 1969). By just using ZWA and PTA, the physics of the "recharge oscillator" can be tested robustly, with one degree of freedom less than the conceptually similar FSU model. Overall, our model shows good potential for ENSO prediction during the spring predictability barrier by a very simple method.

Barnston et al. (2012) note that ENSO forecast skill is generally lower after the year 2000. A comparison of the $R^{2}$ before and after the year 2000 is shown in Figs. 3a,b. Here, we again used $5 \mathrm{yr}$ for validation; that is, from the 20 (17) yr of the 1980-99 (2000-16) subperiod we randomly selected 15 (12) yr to calculate the $\alpha$ and $\beta$ coefficients in Eq. (1), determined $R^{2}$ from the remaining $5 \mathrm{yr}$, and repeated the procedure until the resulting mean $R^{2}$ (shown as a block solid line) converged for each subperiod. For comparison we added the mean $R^{2}$ for the full 1980-2016 period (see Fig. 2a) as a black dashed line. As expected, the cross-validated $R^{2}$ for the 1980-99 subperiod are significantly higher compared to the $2000-16$ subperiod. For $2000-16$, the cross-validated mean and AIC optimized $R^{2}$ drops below 0.5 for LT $>6$ and LT $>7$, respectively, whereas for $1980-99, R^{2}$ remains larger than 0.6 even for $\mathrm{LT}=9$. As can be seen from the minima of the whisker plots in Figs. 3a,b, the small $R^{2}$ for some of the 5-yr validation sets for the full 1980-2016 period in Fig. 2a are dominated by years between 2000 and 2016. The spread between first and third quartiles is significantly smaller for the pre-2000 than for the post-2000 period. The meanAIC optimized $R^{2}$ for the early period is significantly larger than mean-AIC optimized $R^{2}$ for the full period, 
whereas mean-AIC optimized $R^{2}$ for the later period is significantly lower than this, particularly for long lead times.

The corresponding comparison of the cross-validated $R^{2}$ with other models for each subperiod is shown in Figs. $3 \mathrm{c}$ and $3 \mathrm{~d}$, respectively. For the time before the Pacific climate shift in the late 1990s (Hong et al. 2014), our forecast system is slightly less skillful than the CPC CA for all lead times and more or less in the ballpark of others, which become more and more skillful with shorter lead times. After the year $2000, R^{2}$ for all models decreases. However, the $R^{2}$ for our model does not decrease as much as for other models. For the long lead times LT $=9$ to 4 , our model outperforms all other models except for NCEP CFS when compared with the cross-validated mean $R^{2}$ for our model but is as good as NCEP CFS when AIC optimized $R^{2}$ are considered. For $\mathrm{LT}=3$ and shorter, the explained variance of NOAA CFS and CPC Markov is higher than for our model. Interestingly, the difference between the 5-yr mean cross-validated $R^{2}$ and $R^{2}$ based on a full hindcast in our model is hardly noticeable for the 1980-99 subperiod (Fig. 3c), whereas this difference is much larger for the 2000-16 subperiod. This difference is a reflection of the negative skewness of the $R^{2}$ distribution from the cross validation and largely disappears when the AIC optimized $R^{2}$ are considered instead.

A number of recent studies have stated that the lower skill after 1998 is due to a reduced influence of the ocean heat content on Niño-3.4 SSTA predictions (e.g., Horii et al. 2012; McPhaden 2012; Bunge and Clarke 2014). In Fig. $4 \mathrm{a}$, the ratio of $\beta / \alpha$ is shown as a function of lead times when the coefficients are optimized for each individual period before and after the climate regime shift and for the 1980-2016 period as a reference. A larger ratio means ZWA have a stronger influence on the SSTA evolution than the initial oceanic recharged-discharged state. Before the climate regime shift (1980-99), westerly ZWA are more important, especially during the boreal spring period. Westerly ZWA are sustained at shorter LT in maintaining the SSTA. After the climate regime shift (2000-16), the initial recharged state becomes more important in predicting the SSTA than the forcing from ZWA. This contradicts the aforementioned studies. Studies like Bunge and Clarke (2014) analyzed the relationship between SSTA and the OHC across the entire tropical Pacific, but the changes in the mean state are different for WP and EP and partially compensate with an overall more La Niña-like mean state and cooler than usual EP (Fig. 5b). The correlation with the OHC across the entire tropical Pacific has therefore decreased because the changes in EP do not directly influence the Niño-3.4 SSTA evolution, whereas the WP recharge state does. Taking the entire tropical Pacific's mean OHC includes less relevant information that degrades the predictive skill for Niño-3.4 SSTA. In our analysis, we concentrate on the WP OHC since this remotely forces the EP SSTA through the thermocline feedback via eastward-propagating Kelvin waves generated in that region (Fedorov et al. 2015; Lai et al. 2015).

To analyze this further, Figs. 4b-e show the contributions of PTA and ZWA to the predicted Niño-3.4 SSTA in our model, normalized to a $1^{\circ} \mathrm{C}$ observed warming and for El Niño events only. As already seen in Figs. 3a,b, the spread of the predicted contributions is significantly larger after 2000. For the 1980-99 subperiod both factors, PTA and ZWA contribute on average positively to the Niño-3.4 SSTA at all lead times. The distributions of the individual contributions are symmetric and relatively narrow since the first and third quartiles are within $\pm 0.1^{\circ}-0.2^{\circ} \mathrm{C}$ of the mean, and mean and median values agree very well. Both contributions add to $0.5^{\circ} \mathrm{C}$ for $\mathrm{LT}=9$. This sum increases to $0.9^{\circ} \mathrm{C}$ for $\mathrm{LT}=0$. By construction and for perfect predictions both normalized contributions would add to $1^{\circ} \mathrm{C}$. Thus, our model on average underpredicts warm events. This is because our model has been optimized for all years including neutral and cold years and not just warm years. The 2000-16 subperiod behaves very differently. At longer lead times (LT > 4), ZWA has on average a negative contribution even when positive SSTA were observed. For short lead times $(\mathrm{LT}<3)$ and compared to the 1980-99 subperiod, ZWA contributes only about half as much to the predicted SSTA. The distributions of the individual contributions are skewed toward negative numbers so that, with few exceptions, median values are larger than mean values. This is even more evident for the PTA contributions in Figs. 4b and 4c. Before 2000 there is practically no difference between median and mean PTA contribution; however, after 1999 the median is much larger than the mean. For the later period, the mean is reduced to almost zero whereas the median is much larger than before. Thus, in the mean of all $\mathrm{El}$ Niños, PTA does not seem to contribute after 1999 although for a significant number of cases the PTA contribution is much larger than before since the median value is much larger after 2000 than before. As shown by the whiskers, even after 1999 the OHC contribution is positive in over $75 \%$ of all cases. There are a few El Niños, mainly CPENs, where the WP in the selected region during November in the year before the event has a strongly negative $\mathrm{OHC}$ anomaly. It is these few cases with strong negative $\mathrm{OHC}$ anomaly, and thus negative PTA contribution, that cause the zero mean despite the overwhelming number of cases with positive PTA contribution. This supports our conclusion from 
(a)

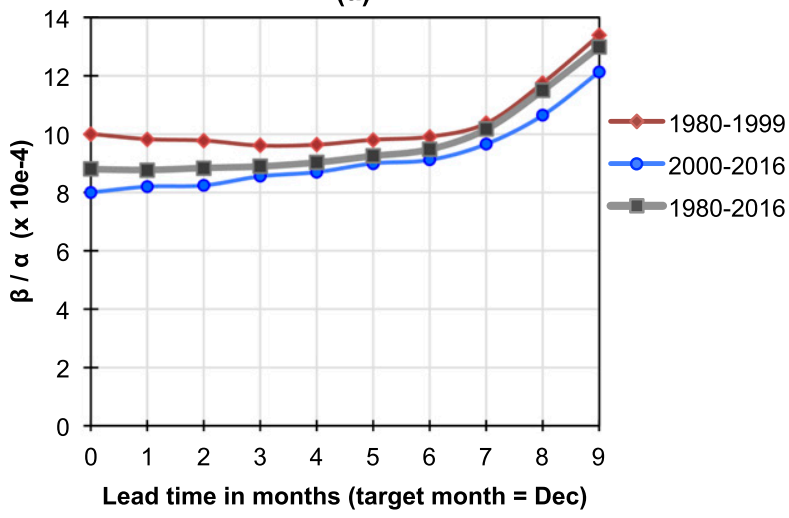

(b) Normalised $\alpha(\Delta \theta / \bar{\theta})$ for EN during 1980-1999

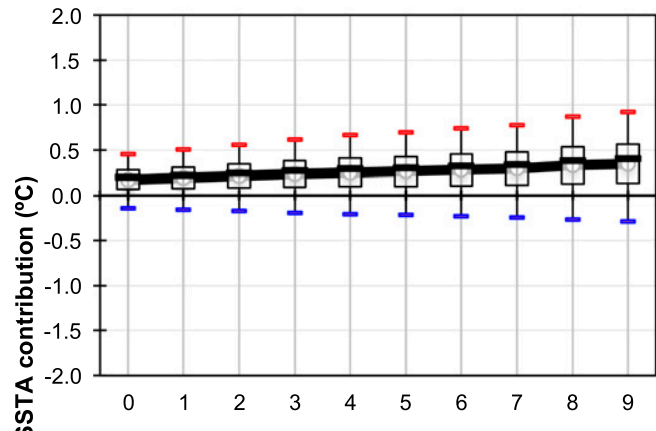

(d) Normalised $\beta\left(\sum \Delta U / \bar{U}\right)$ for EN during 1980-1999

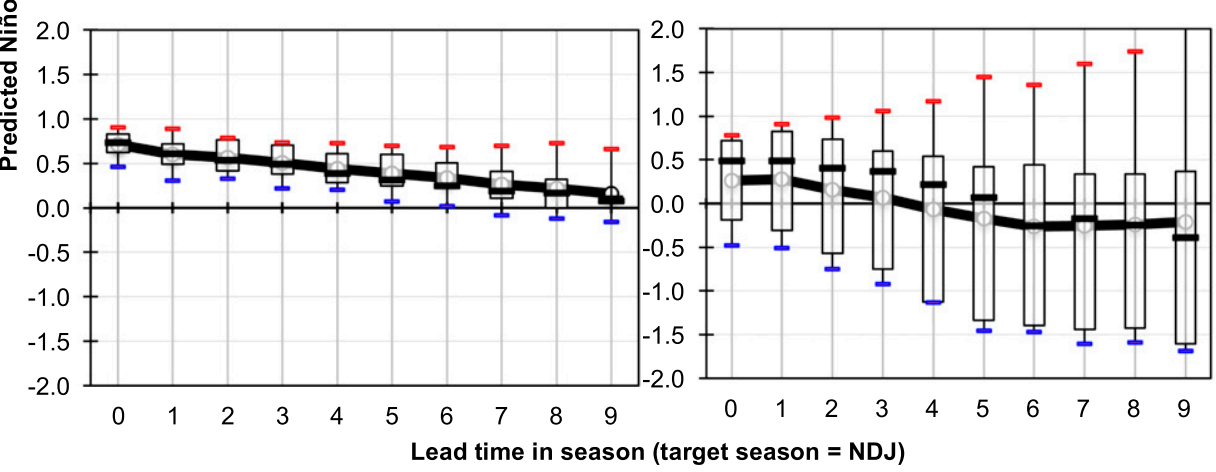

(c) Normalised $\alpha(\Delta \theta / \bar{\theta})$ for EN during 2000-2016

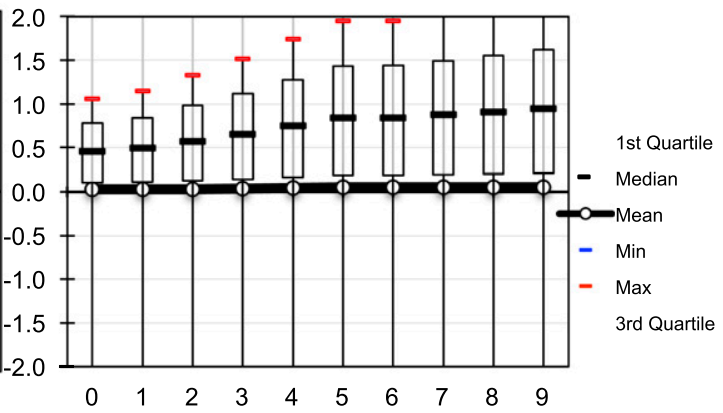

(e) Normalised $\beta\left(\sum \Delta U / \bar{U}\right)$ for EN during 2000-2016

FIG. 4. (a) The ratio $\beta / \alpha$ when these two coefficients are optimized for individual periods of 1980-99 (red) and 2000-16 (blue). (b),(c) Whiskers of the distribution of Niño-3.4 SSTA contributions from PTA normalized to $1^{\circ} \mathrm{C}$ observed warming for 1980-99 and 2000-16, respectively. (d),(e) As in (b) and (c), but for contributions from ZWA.

Fig. 4a that PTA and, therefore, OHC has become more important in the later subperiod.

\section{b. Changes in key parameters after the year 2000}

Further investigating the effect of the Pacific climate regime shift, we examine potential mechanisms influencing forecast skill for 1980-99 and 2000-16. For El Niño events, Figs. 5 and 6 show the composites of the February(0) PTA and the ZWA Hovmöller diagrams of these two periods, respectively. The black rectangles indicate the domain from which the data are taken for our ENSO predictions. Within our PTA domain there are positive PTA indicating a recharged state for both periods (Figs. 5a,b). Although areas of statistical significance are small due to the small sample size and the high variability between El Niño events, the composites suggest that after the year 2000, the WP is in a more recharged state and that the region of recharge is more confined toward the westernmost portion of the equatorial Pacific. In the EP, statistically significantly colder water masses extend toward $120^{\circ} \mathrm{W}$.

Strong evidence of the climate regime shift can also be seen in the ZWA Hovmöller diagrams in Figs. 6a and 6b. 


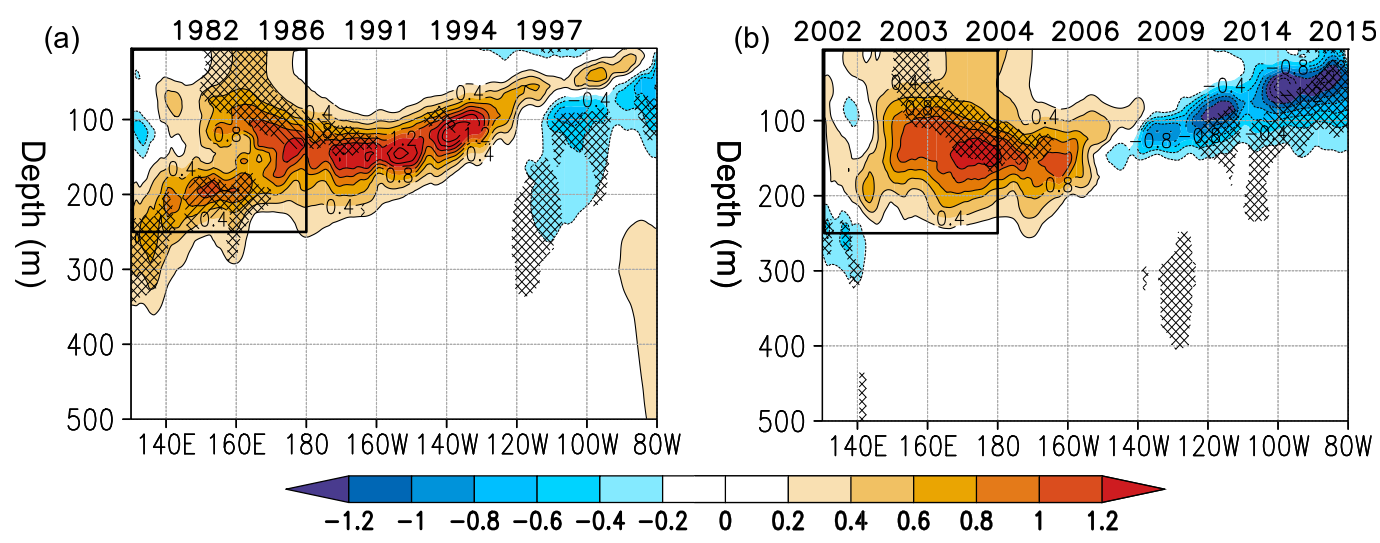

FIG. 5. El Niño events composites of the February $(0)$ PTA $(\mathrm{K})$ as a function of depth averaged over $5^{\circ} \mathrm{N}-5^{\circ} \mathrm{S}$. The following El Niño events are included: (a) 1982, 1986, 1991, 1994, and 1997 and (b) 2002, 2003, 2004, 2006, 2009, 2014, and 2015. The black rectangles are the domain used in our forecasting model. The hatching indicates a statistical significance at the $95 \%$ confidence level based on the Student's $t$ test.

Westerly ZWA are much stronger before 2000, and over time they gradually extend into the central-eastern $\mathrm{Pa}$ cific. The domain used in our model captures the temporal and spatial patterns of the westerly ZWA well during 1980-99. However, after 2000 the ZWA patterns have changed. Westerly ZWA are weaker and more confined toward the WP. Furthermore, westerly ZWA occur later, starting only around $\operatorname{May}(0)$. There are also notably stronger easterly ZWA at long lead times (February-April) that contribute to negative cumulative ZWA when the sampling area is kept too close to the date line. The analysis of individual El Niño events (shown in Lai et al. 2015) indicates that these easterly ZWA are one of the main reasons for the underprediction of some warm events. The strengthened easterly winds also explain the cooler subsurface oceanic water masses over the EP. Stronger easterly winds enhance surface divergence and upwelling of cold water from the deep ocean, and, therefore, the mean state of the equatorial Pacific becomes more La Niña-like (e.g., Hong et al. 2014; Bunge and Clarke 2014). Figures 7a and $7 \mathrm{~b}$ show the NDJ SSTA for El Niño events before and after 2000, respectively, thus the SSTA that our model is designed to predict with input from Fig. 5 and 6. Figure 7 confirms the transition from a more EPEN-like pattern to a more CPEN-like pattern. As discussed in the introduction, many studies suggest that external forcings from outside the Pacific basin contributed to the climate regime shift with the tropical Atlantic playing an important role. Underlying processes and mechanisms are complex and beyond the focus of this study. Here we only focus on the effect that these external factors have on ZWA in the tropical Pacific.

The 2009/10 event is an example of an underpredicted El Niño (Fig. 8a). The event is also not well predicted by many statistical models during boreal spring-early summer. Most models start off with a negative SSTA prediction during February(0) and $\operatorname{March}(0)$. The two dynamical models (NOAA CFS and NASA GMAO), however, manage to predict the El Niño event, because dynamical models are more sensitive to the initial condition of the ocean (Barnston et al. 2012) and the western Pacific is recharged at this time (Fig. 8b). The main reason for the underprediction is the strong La Niña during the previous year with persistent strong easterly ZWA until April 2009 (Fig. 8c). Westerly ZWA are weak or absent early in the year of 2009 and occurred farther to the west, outside of our domain. As a result, the cumulative ZWA values are initially strongly negative for our forecast model, so that our model only predicts a neutral-to-weak El Niño event later in the year starting around August 2009. The strong easterly ZWA during boreal spring are also the main cause of most underpredictions of the statistical models because the ZWA pattern resembles that of an $\mathrm{LN}$ event, and the oceanic conditions take time to evolve into an El Niño.

To further explore relevant features of the two climate regimes (Chen and Wallace 2015; Hu et al. 2013; Lyon et al. 2014; McPhaden et al. 2011; Hong et al. 2014; Wen et al. 2014) and their relation to the change in forecast skill, Fig. 9 displays the difference of after (200116) minus before (1980-96) the climate regime shift for the four seasons of sea level pressure (SLP) and precipitation. Boreal spring, summer, autumn, and winter are the 3-month mean of March-May (MAM), June-August (JJA), September-November (SON), and December-February (DJF), respectively. Figure 10 shows Hovmöller diagrams of ZWA. Note that the transition period 1997-2000 is excluded, although 
(a) ZWA (m/s) Composite: 19821986199119941997

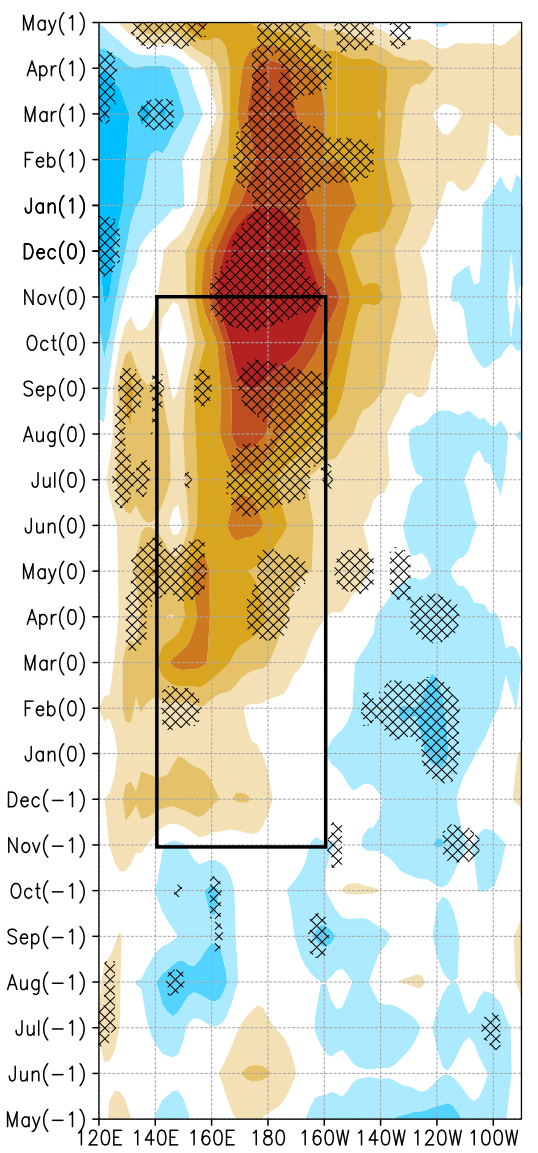

(b) ZWA (m/s) Composite: 2002200320042006200920142015

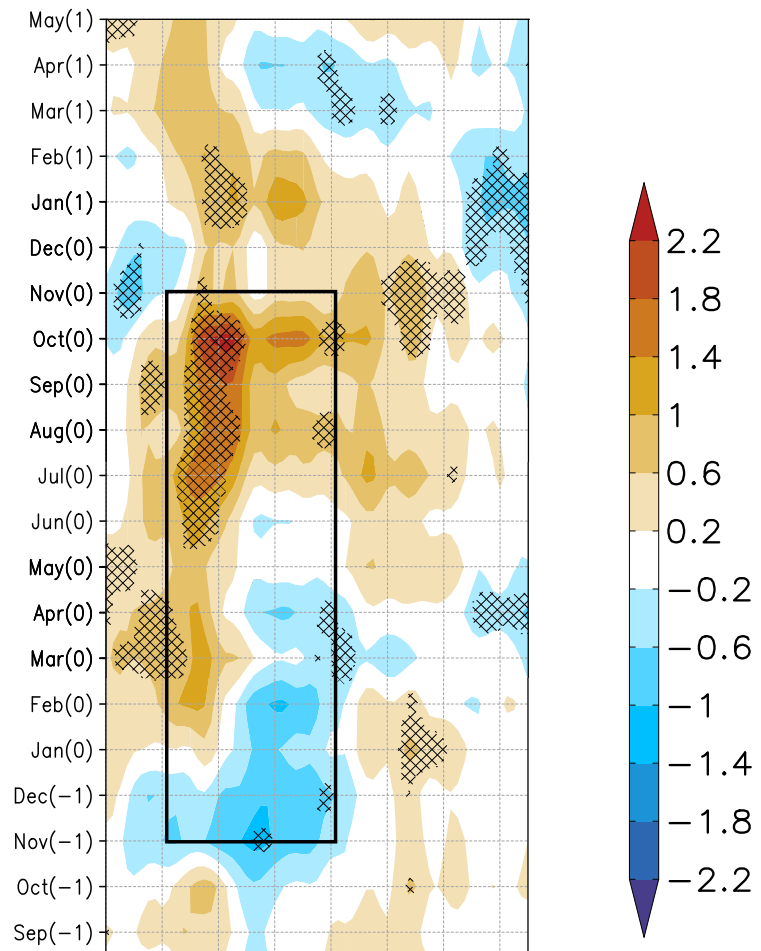

FIG. 6. As in Fig. 5, but for Hovmöller plots of ZWA ( $\mathrm{m} \mathrm{s}^{-1}$ ) from May(-1) to May(1).

results are not sensitive to the removal of any year during 1997-2000 period (not shown).

The SLP in Fig. 9a shows a zonal pattern in the Pacific with increased pressure over the EP and decreased pressure over the WP warm pool and Indian Ocean. The North and South Pacific subtropical highs have strengthened mainly during boreal winter and spring. This leads to an intensification of the Hadley cell across the EP and stronger trade winds in equatorial regions. In the Southern Hemisphere this strengthening of the Hadley cell is noticeable throughout the year, whereas in the north this is only the case for boreal winter and spring. Figure $9 \mathrm{~b}$ indicates a similar zonal dipole pattern of drier conditions around the $\mathrm{CP}$ and $\mathrm{EP}$ regions and more precipitation over the Indo-Pacific warm pool. Figure 10 shows that ZWA around the CP have undergone pronounced (a) Pre-CSR NDJ EI Niño lat-lon SSTA

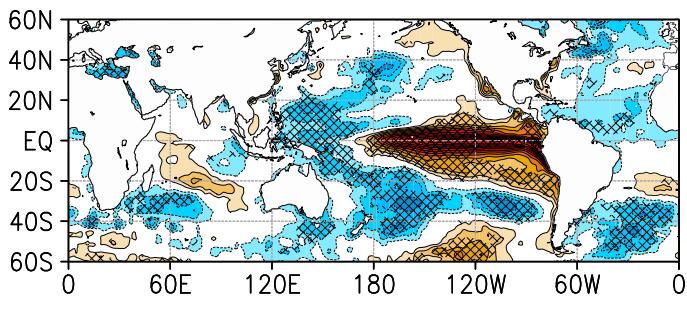

(b) Post-CSR NDJ El Niño lat-lon SSTA

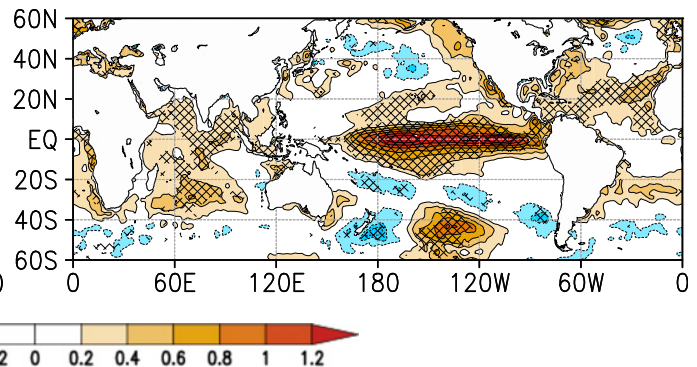

FIG. 7. As in Fig. 5, but for the NDJ SSTA pattern. 
(a) Nino3.4 Prediction of NDJ 2009-10
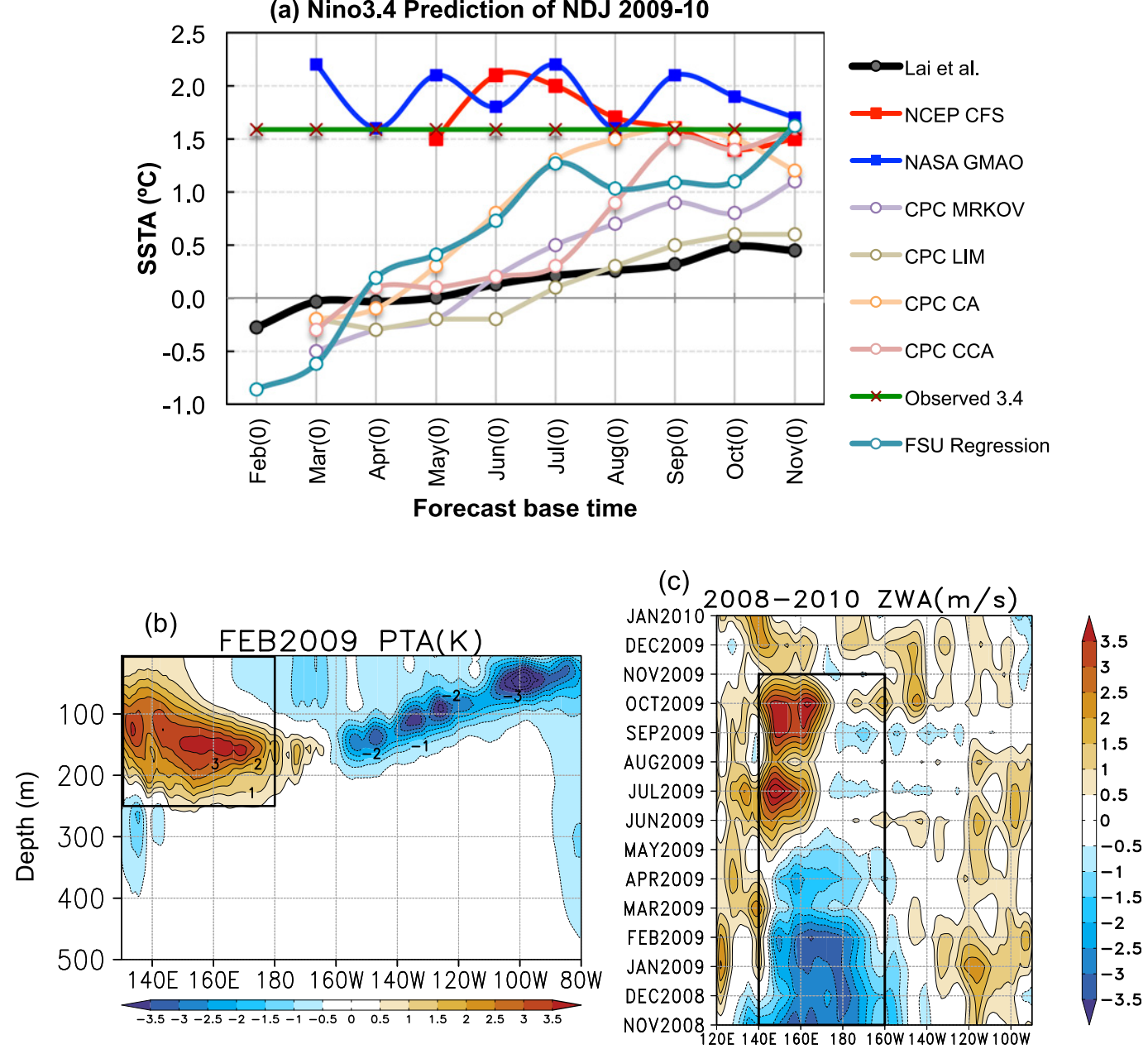

FIG. 8. (a) Niño-3.4 NDJ SSTA predictions for each forecast base time starting in February(0). The black line is our model, and green line is the observed Niño-3.4 NDJ SSTA. (b) February 2009 PTA (K). (c) November 2008 to January $2010 \mathrm{ZWA}\left(\mathrm{m} \mathrm{s}^{-1}\right)$. The rectangle indicates the domain used to obtain data for our forecasting model.

changes. There were westerly anomalies before the climate shift, but those anomalies have become strong easterlies after the early 2000s. The Pacific zonal pressure gradient has led to an intensified low-level airflow from the EP to WP. This intensification of the Walker cell is weakest during JJA but noticeable throughout the year. Higher pressure over the EP also suppresses convective activities; conversely, lower pressure over the WP warm pool area enhances convections as seen in Fig. 9b. All these atmospheric responses indicate that the recent trade winds have increased due to a strengthening of both the Walker and Hadley cells. In response, this has led to a more La Niña-like background mean state.

\section{Discussion}

The strengthening of the Pacific subtropical highs, and, thus, strengthening of the Hadley cell is consistent with increase in trade winds, hence the stronger easterly ZWA in recent decades (England et al. 2014). Consequently, the chance of anomalous wind convergence around the $\mathrm{CP}$ has increased even when there are westerly ZWA, as shown in Fig. 6b, which is a favorable condition for the occurrence of CPEN. We find a westward displacement of the anomalous wind forcing associated with ENSO after 1999, which supports the findings in Bunge and Clarke (2014). This is consistent with more frequent CPEN in the recent decades, especially after around the year 2000 (e.g., Xiang et al. 2013; Chung and Li 2013). Furthermore, despite the strongly recharged state of the WP that might have normally led to Kelvin waves for an EP-type El Niño to develop if the westerly ZWA would have allowed, CP-type El Niños still dominate (Chung and Li 2013; Lai et al. (2015).

The more persistent easterly trade winds have led to a stronger recharged state over the WP. According to 
(a)
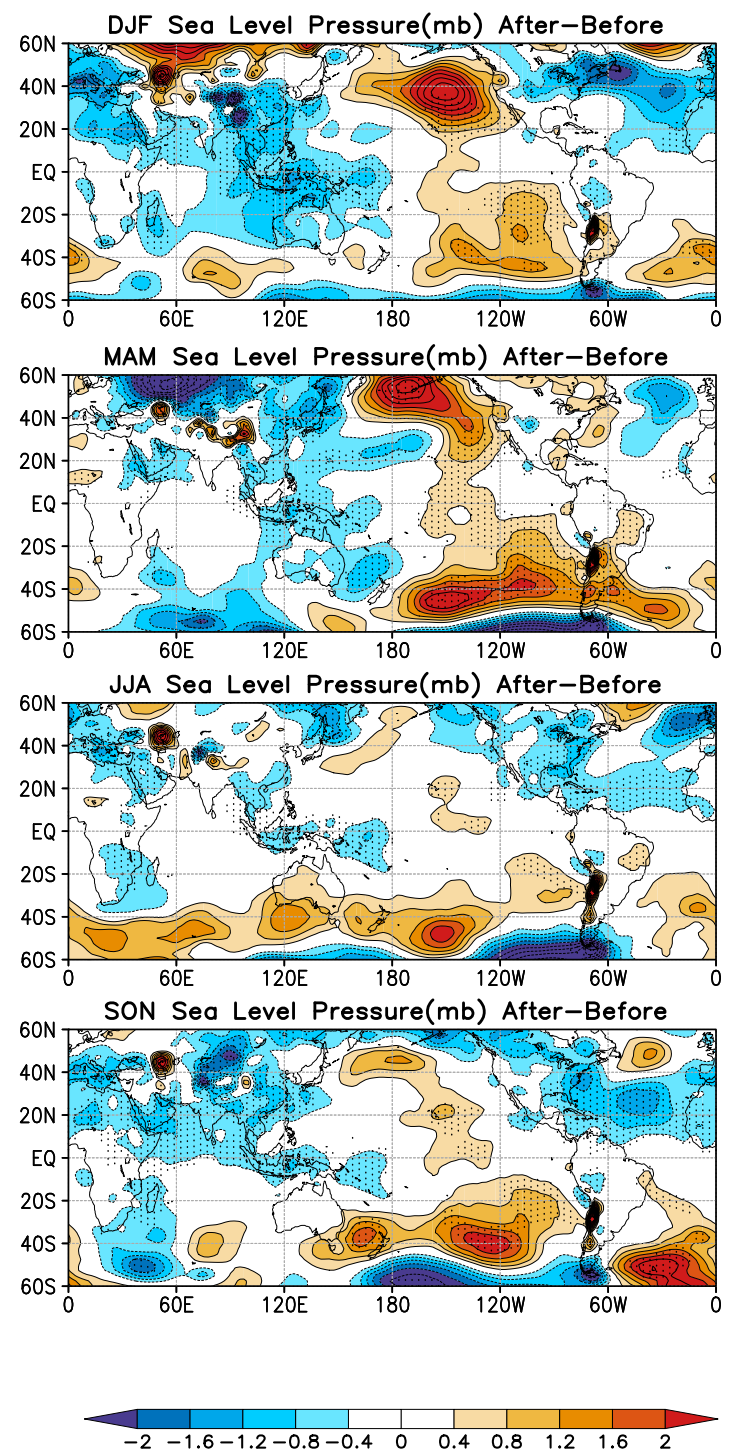

(b)
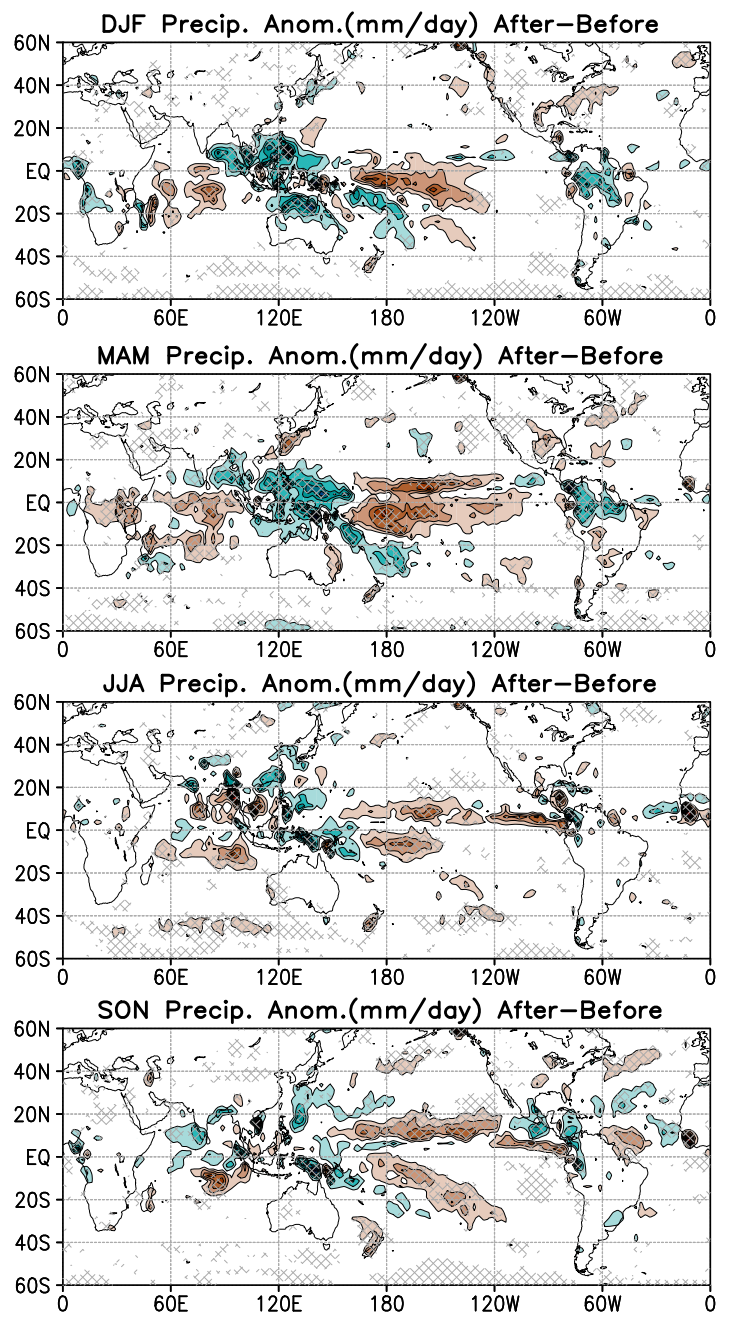

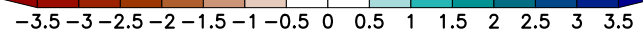

FIG. 9. Differences of the period post-climate regime shift 2001-16 minus pre-climate regime shift 1980-96 for (top)-(bottom) the DJF, MAM, JJA, and SON 3-month mean of (a) sea level pressure (mb) and (b) precipitation anomalies ( $\mathrm{mm} \mathrm{day}^{-1}$ ). Dots and hatching denote the $95 \%$ statistical significance level using the Student's $t$ test.

some studies, there are signs that the Indian Ocean warming now extends into the WP, where the WP warm pool gets warmer, and its eastern edge extends farther eastward (e.g., Rao et al. 2012; Cravatte et al. 2009). Warmer water over the Indo-western Pacific enhances convective activity, leading to more precipitation and lower SLP. This lower SLP increases the pressure gradient across the equatorial Pacific thereby strengthening the Walker circulation. This together with the aforementioned strengthening of the Hadley cell further enhances easterly wind anomalies in the lower troposphere over the eastern part of the equatorial Pacific. This can be further examined by the divergent component of the horizontal flow and vertical motion (Krishnamurti 1973). Figure 11 shows the 200- minus 850 -mb velocity potential (shaded) and the 200-mb divergent wind at the $95 \%$ statistical significance level (vectors). Negative velocity potential implies rising air motion that is associated with deep convection and diverging wind at the upper troposphere of $200 \mathrm{mb}(1 \mathrm{mb}=1 \mathrm{hPa})$. Figure 11 indicates that stronger rising air motion and upper-tropospheric divergence over the warm pool enhance the Hadley cell and further strengthen the subtropical high pressure systems. Such motions are strongest during boreal spring. This accelerates trade winds and increases equatorial upwelling in the central and eastern Pacific, thereby 

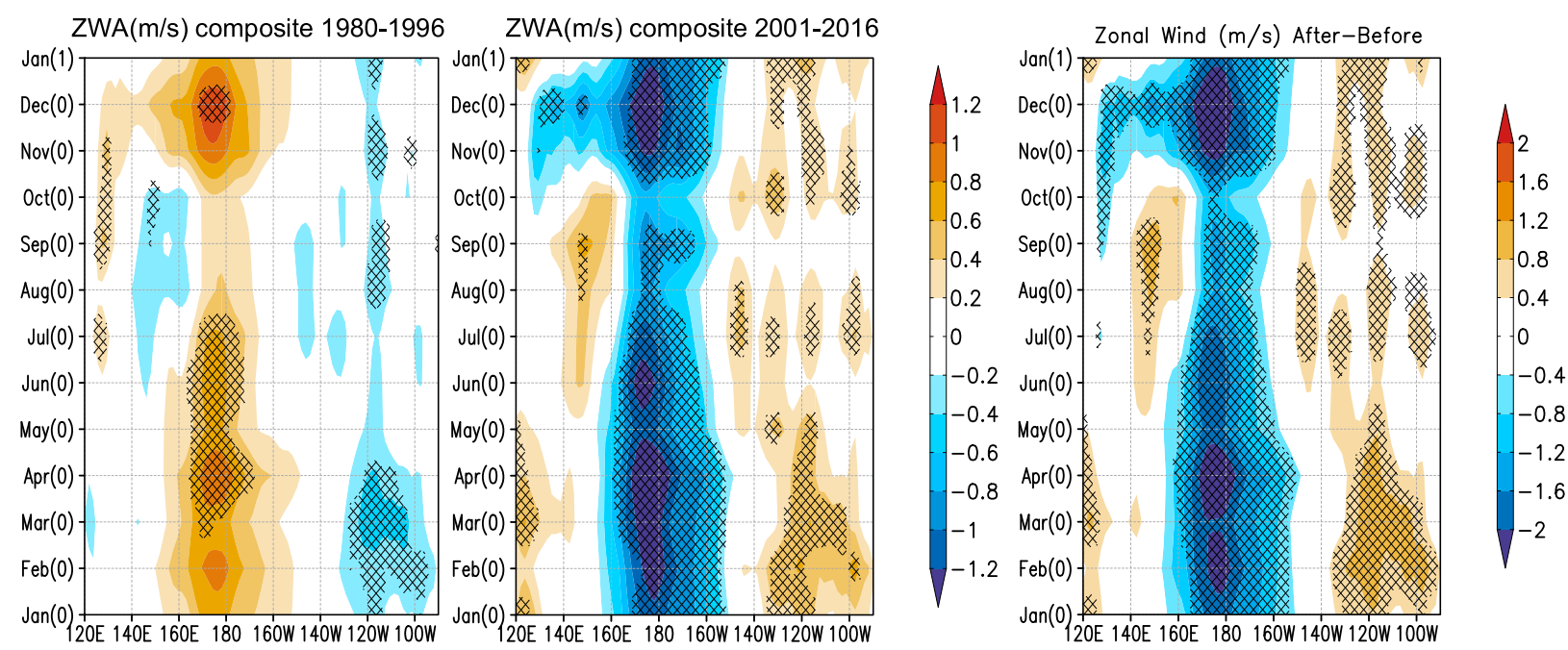

FIG. 10. As in Fig. 8, but for Hovmöller of zonal wind anomalies composites of the period: (left) pre-, (center) post-, and (right) post- minus pre-climate regime shift. Hatching denotes the $95 \%$ statistical significance level using the Student's $t$ test.

lowering the SST there. As a result, a La Niña-like mean state is developed, with less precipitation over the EP (Fig. 9b). Figure 11b shows the seasonally varying mean SSTA before minus after the climate regime shift. SST gradients significantly increased in the north-south direction (between $40^{\circ} \mathrm{S}$ and $40^{\circ} \mathrm{N}$ around $160^{\circ} \mathrm{E}-160^{\circ} \mathrm{W}$ ) as well as in the east-west direction along the equator. This is consistent with the already-mentioned intensification of Hadley as well as Walker cell.

More CPEN mean that ENSO forecasting is more challenging because the onset and evolution of CPEN is mainly governed by a local zonal advection feedback (Fedorov et al. 2015; Chen et al. 2015; Lai et al. 2015). Such a mechanism is subject to atmospheric stochastic zonal wind forcing, for instance westerly wind bursts, which are difficult to predict (Gebbie and Tziperman 2009). Because westerly ZWA are associated with many different processes, including extratropical cold surges (Kiladis et al. 1994; Chen et al. 2013), tropical cyclones (Keen 1982; Hartten 1996), the Madden-Julian oscillation (DeMott et al. 2015; Puy et al. 2016), or a combination of all (Yu and Rienecker 1998), westerly ZWA are sometimes assumed to be part of the "weather noise" with the timing of individual bursts difficult to predict. In addition, El Niño-related SSTA modulate westerly ZWA; therefore, the ZWA should not be regarded purely as a stochastic forcing (Eisenman et al. 2005). However, the coupled dynamics that act to confine the SST warming over the CP for a CPEN is still not fully understood. For instance, it is not yet clear why some westerly ZWA initiate anomalous $\mathrm{CP}$ warmings that are sufficiently sustained to become a CPEN event and some do not. The role of thermocline feedback is still controversial. Kao and $\mathrm{Yu}$ (2009), Kug et al. (2009), and Lai et al. (2015) agree that equatorial thermocline variations are not crucial in producing CPEN. However, Ashok et al. (2007) and Marathe et al. (2015) still emphasize the importance of wind-induced thermocline variations within the tropical Pacific to the SST evolution of CPEN. Based on case studies, Yu and Kim (2010) and $\mathrm{Su}$ et al. (2014) note that there is a large variety of CPEN. Their initiation and evolution depend on the equatorial recharged state and the influence from the subtropical SSTA. A model study by Choi et al. 2011 is consistent with our findings from observations; the background state of the tropical Pacific can produce ocean and atmospheric conditions that favor the generation of CPEN or EPEN events. On the other hand, the genesis of a canonical EPEN involves the thermocline feedback mechanism as part of the Bjerknes feedback, which is well understood via the delayed oscillator theory (Bjerknes 1969; Suarez and Schopf 1988) and the recharged-discharged oscillator theory (Jin 1997). Once major Kelvin waves are triggered, the EP SSTA are more predictable than during its CPEN counterpart.

A WP recharged state is necessary but not sufficient to trigger Kelvin waves that cause significant EP warming. Westerly ZWA over the western-central Pacific are needed to displace the WP warm pool eastward, triggering Kelvin wave propagation and suppressing EP upwelling. The level of constructive or nonconstructive superposition of both parameters will result in a range of El Niño intensities, which is the El Niño continuum, with CPEN and EPEN as end members (Lai et al. 2015). 
(a)

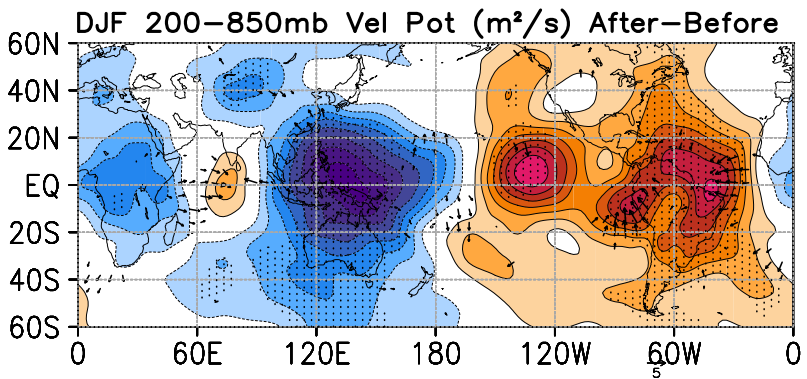

60N JJA 200-850mb Vel Pot $\left(\mathrm{m}^{2} / \mathrm{s}\right)$ After-Before

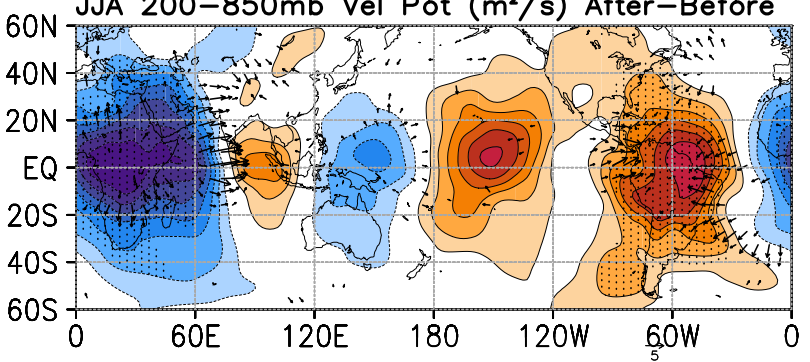

MAM 200-850mb Vel Pot $\left(\mathrm{m}^{2} / \mathrm{s}\right)$ After-Before

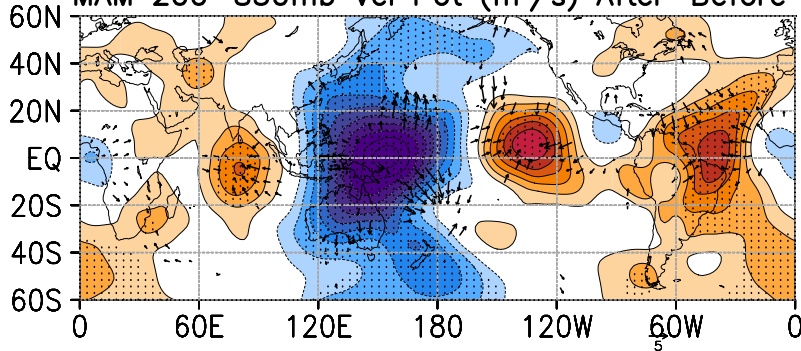

SON 200-850mb Vel Pot $\left(\mathrm{m}^{2} / \mathrm{s}\right)$ After-Before

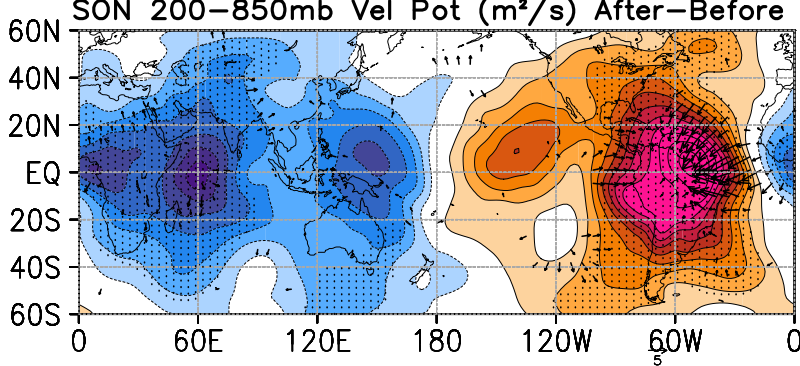

\begin{tabular}{lll|l|l|l|l|l|l|l|l}
-4 & -3 & -2 & -1 & 0 & 1 & 2 & 3 & 4
\end{tabular}

(b)
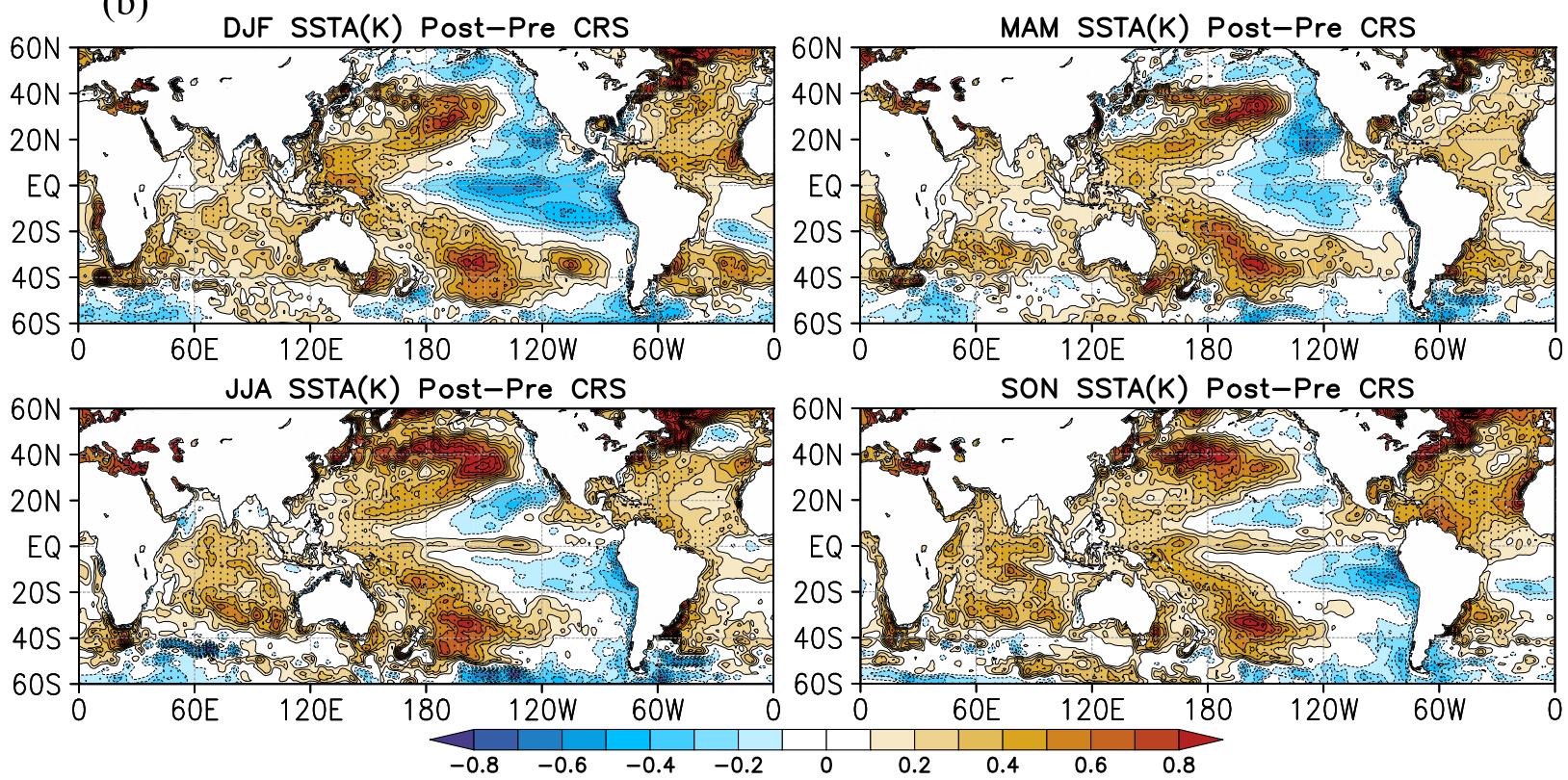

FIG. 11. As in Fig. 8, but for (a) 200-mb minus 850-mb velocity potential $\left(\mathrm{m}^{2} \mathrm{~s}^{-1} \times 10^{6}\right.$; color shaded) and 200-mb divergent wind (m s ${ }^{-1}$; vectors, reference vector below each panel under the $60 \mathrm{~W}$ ). Dots and vectors denote the $95 \%$ statistical significance level using the Student's $t$ test for velocity potential and divergent wind, respectively, and for (b) the mean SSTA after minus before the climate regime shift.

Since Eq. (1) is mainly based on the thermocline feedback mechanism, the model works less well for CPEN, because CPEN is caused by local air-sea interaction and zonal advection feedback (Kao and Yu 2009; Kug et al. 2009; Yeh et al. 2014; Choi et al. 2011). The coefficient $\beta$ includes the combined effects of thermocline feedback, zonal advection, turbulent flux, and heat flux due to zonal wind forcing on SST. The model might be improved by disentangling $\beta$ into more coefficients that are associated with different processes. For instance, one coefficient could be used for the basinwide thermocline feedback and others for local processes such as local 
divergence and turbulent fluxes. Another way to improve our model would be to try to add terms to explicitly present remote forcing, for example, from the tropical Atlantic. However, this would have the issue of double counting. In our current approach local and remote factors influencing ZWA are considered together. Before adding terms for remote forcing, their influence on ZWA would need to be separated from the total ZWA. Since to our knowledge no simple relationship between remote forcing and local effect on Niño-3.4 SSTA has been identified, and given the already high $R^{2}$ of our model compared to other methods (Fig. 2), such an improvement would be very difficult. We believe that a full dynamical forecast model is needed to capture local and remote forcing factors in a meaningful way.

During 1980-99, the PTA shows an initial recharged state that extends farther to the east than after 2000. The westerly wind anomalies are strong during El Niño events within this earlier period, covering most of the domain used in our model. Therefore, the theory of a rechargeddischarged oscillator (Jin 1997) and the delayed oscillator (Suarez and Schopf 1988) as well as atmospheric forcing such as the westerly wind anomalies (Fedorov et al. 2015; $\mathrm{Hu}$ et al. 2014; Lai et al. 2015) works well for ENSO predictions before the Pacific climate shift.

After 2000, the WP warms accompanied by EP cooling. This could be due to the recent rapid Indian Ocean and warm pool warming (Cravatte et al. 2009; Rao et al. 2012; Luo et al. 2012) or the recent negative phase of the Pacific decadal oscillation (England et al. 2014; Lyon et al. 2014). This facilitates the strengthening of the easterly trade winds, Walker circulation, subtropical highs, and Hadley cell (England et al. 2014). Cai et al. (2015) also found that under global warming, the Indonesian Maritime Continent is warming faster than the equatorial $\mathrm{CP}$ to EP region. The increasing zonal temperature gradient between the two can drive stronger anomalous zonal easterly winds. In addition, the recent North Atlantic warming potentially contributed to the intensification of the Walker circulation through upward motion and lower SLP over the Atlantic and an enhanced descending air motion and higher pressure in the eastern Pacific, which in turn strengthened the trade winds over the central tropical Pacific (McGregor et al. 2014; Li et al. 2015; Zanchettin et al. 2016). This is consistent with Fig. 9a. Strong 200-mb divergence (convergence) is observed over the eastern Atlantic (western Atlantic and EP) in Fig. 11. The latter is indicative of a remote forcing from the Atlantic basin as discussed in the introduction (e.g., Kucharski et al. 2011, 2016; Zhang and Karnauskas 2017).

Other studies have already shown that the warm water volume (mean upper $\mathrm{OHC}$ of the $120^{\circ} \mathrm{E}-80^{\circ} \mathrm{W}$ equatorial
Pacific) has a weaker correlation with the Niño-3.4 region since 2000 (Horii et al. 2012; McPhaden 2012; Wen et al. 2014). Our study shows that this breakdown of the predictor-predictand relationship can partially be addressed if only the WP $\left(130^{\circ} \mathrm{E}-180^{\circ}\right)$ recharged state is considered as an El Niño predictor. This is because, despite the atmospheric forcing, the Niño-3.4 SSTA is remotely forced by the WP recharged state, whereas the EP oceanic state is largely irrelevant. Using the entire tropical Pacific's mean OHC includes less relevant information from the cooler EP in the new climate regime, degrading the predictive skill for Niño-3.4 SSTA.

The weak 2014/15 El Niño event is a recent example of some models not accurately predicting the Niño-3.4 during boreal spring (Menkes et al. 2014). This event attracted much attention because it had a high initial recharged state mainly over the WP in February(0), which is consistent with the previously observed post2000 El Niño events. It was also an unusual event because it had a prolonged CP warming from February 2014 to April 2015, and then a strong EPEN developed from then until July 2016, with intensities being the third strongest on record, just below 1997/98 and 1982/83. Statistically, the warm water volume shows a mean equatorial recharged state similar to the 1997 initial state. Models that are sensitive to this oceanic state have overestimated the event during boreal spring (McPhaden 2015). However, what followed was a lack of continuous westerly ZWA, and therefore the CP warming did not evolve into a fully-fledged EPEN ( $\mathrm{Li}$ et al. 2015). We speculate that since the Pacific is still affected by the strengthened mean easterly trade wind climate regime, the expected strong westerly ZWA failed to develop and to be sustained. This is in line with McPhaden (2015), who claims that the warming trend of the Indian Ocean and Indo-Pacific warm pool might have prevented deep convection to shift toward the CP or EP. The associated increase in precipitation in this area is also evident in Fig. 9b.

For the 2014-15 case, our model (calibrated for the full 2000-16 period) predicted a weak El Niño during the boreal spring (Fig. 12b) close to observations. This is because in our model, although a high initial oceanic recharged state was present, weak cumulative ZWA were also detected. The two parameters did not interact constructively so that a strong EPEN could not develop (Lai et al. 2015). In contrast, other models, for example the FSU, NOAA CFS, and NASA GMAO, overpredicted the El Niño signal earlier in the year. Figure 12a shows that our model, as well as other models, performs very well for 1997/98. However, skills decrease for the 2015/16 EPEN (Fig. 12c). Most models underpredict max SSTA during boreal spring compared to the 1997/98 EPEN 
(a) Nino3.4 Prediction of NDJ 1997-98

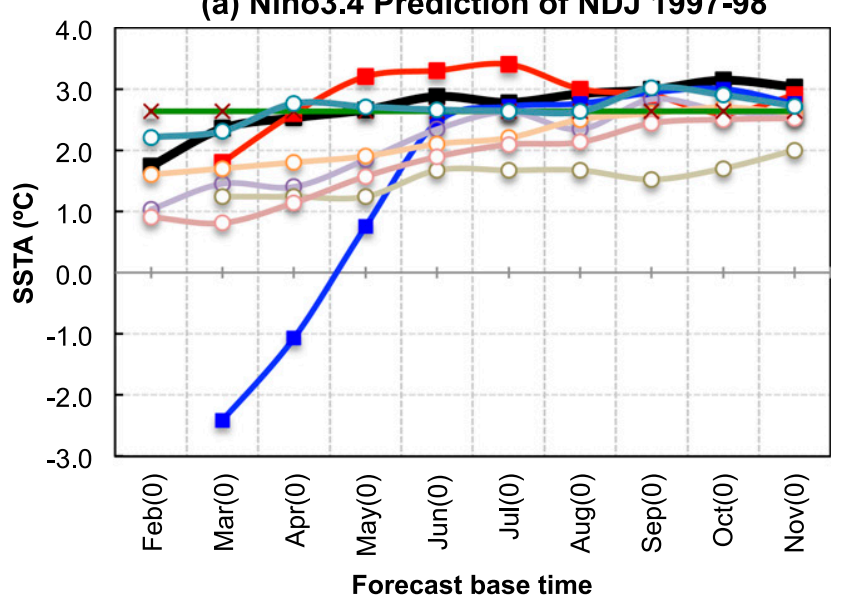

(b) Nino3.4 Prediction of NDJ 2014-15

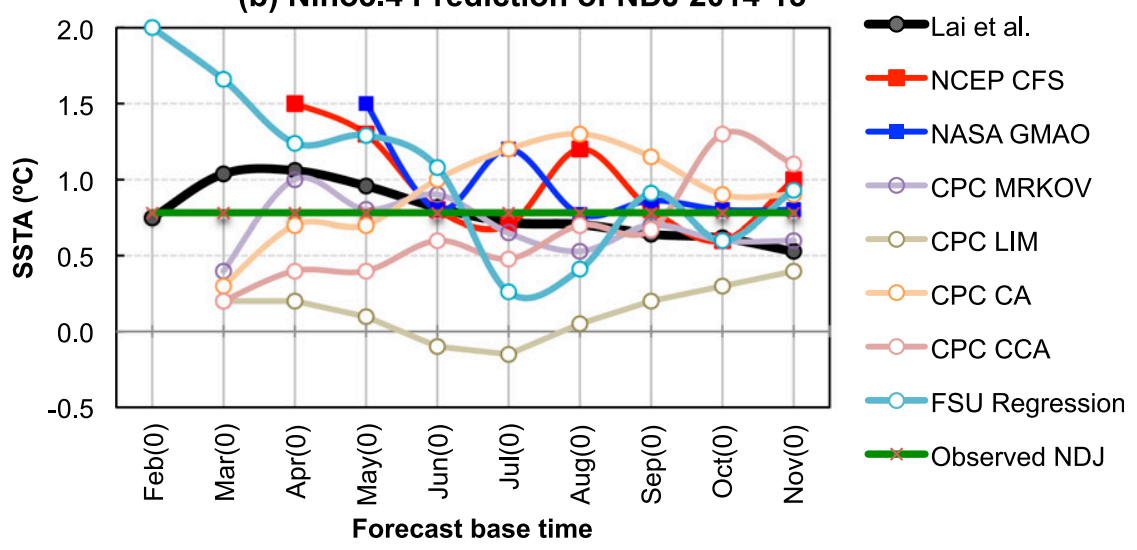

(c) Nino3.4 Prediction of NDJ 2015-16

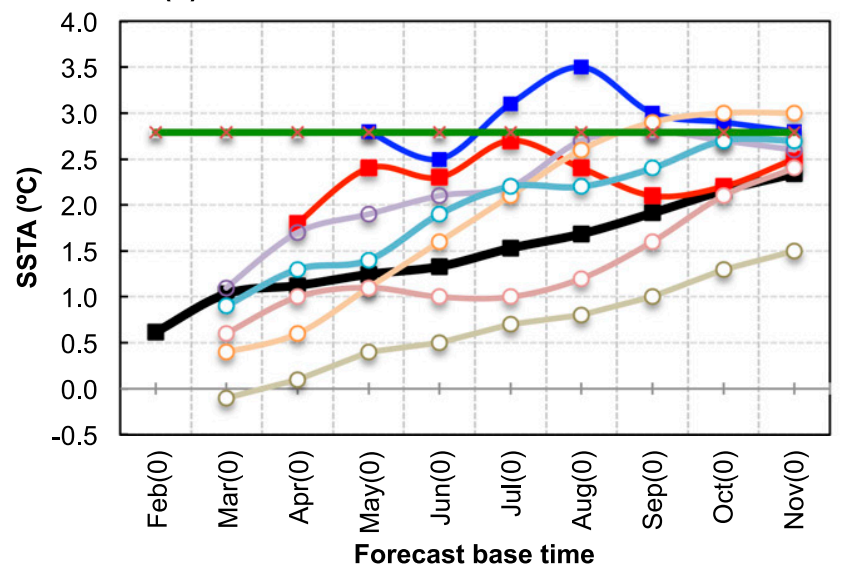

FIG. 12. As in Fig. 7a, but for the NDJ predictions of a 1997/98 Niño-3.4, (b) 2014/15 Niño-3.4, and (c) 2015/16 Niño-3.4.

due to the stronger role of CPEN dynamics for 2015/16 (Paek et al. 2017). Under the new climate regime, easterly winds still dominate the earlier period, leading to a later prediction of a strong El Niño event for various models.
In light of the change in base state, we have repeated our analysis by using the mean state after 2000 to compute the cumulative ZWA rather than the usual practice of using a climatology based on the past $30 \mathrm{yr}$. However, this did not improve our predictions. This implies that 
there are other, yet unidentified processes that have become more important so that the two parameters used here are insufficient to explain the observed variability. Whether other parameters need to be included deserves further research. The reduced El Niño predictability in our model could also be due to the use of a fixed domain to calculate the wind anomalies, which is recently misaligned with the region where positive PTA are found. Easterlies ZWA have shifted into our wind domain causing the skill of our model to decrease. Xiang et al. (2013) have attributed this displacement of westerlies to the west to the more La Niña ocean state after 1999 and an anomalous subsidence in the CP. Testing a shift of the wind area to where the PTA are actually observed might help improve the predictions at long lead times. Processes leading to an initial $\mathrm{CP}$ warming might be of particular importance in predicting the emergence of an El Niño event in the future. Also, the current climate regime could persist if the Indo-Pacific warming continues, favoring more CPEN and suppressed EPEN (Lai et al. 2015).

\section{Conclusions and outlook}

Based on the western-central Pacific cumulative ZWA from November(-1) and western Pacific (WP) recharge-discharge state in February(0), a simple statistical model for predicting the NDJ Niño-3.4 SSTA has been developed [Eq. (1)]. Additional information from observed SSTA is not needed because the main ENSO evolutionary signals are embedded in the upper-ocean heat content.

For the springtime barrier, our model has higher predictive skill than many other models in this study, except the NOAA CFS and CPC CA. On average, our model has $R^{2}=57 \%$ for a lead time LT $=8$, but for other models $R^{2}=50 \%$ at best. Only the weak 2003/04 El Niño event is being predicted to be a cold event at $\mathrm{LT}=4$ to 0 ("wrong" top left quadrant in Fig. 1), while all La Niña data points are in the correct "cold" quadrant and the amplitudes are captured reasonably well.

Our model underpredicts an El Niño event if the PTA domain is in a discharged initial state or if the westerly ZWA occur in late boreal summer. For example, CP warming not due to thermocline feedback dominated initially for the 1994/95 and 2003/04 events. A strong recharged initial oceanic state can lead to Kelvin waves with only small westerly ZWA, like for the 2009/10 El Niño event.

All forecasts after the year 2000 are less skillful due to the Pacific climate regime shift (Hong et al. 2014). However, $R^{2}$ for our model decreases less than for other models, especially for LT $=9$ to 4 . This suggests that the physical mechanisms on which our model is based are less sensitive to the decadal climate change in the $\mathrm{Pa}$ cific. By using the heat content of the WP as a predictor, our model better maintains skill for the post-2000 El Niño events compared to statistical models that are based on the ocean heat content for the entire tropical Pacific. Our analysis shows that the influence of the WP recharge state on ENSO predictions has increased after 2000 , contrasting previous studies where the recharge state is based on the ocean heat content for the entire tropical Pacific.

To further investigate cause and effect and to understand the underlying physical processes that characterize the climate regime shift and the reduction in ENSO forecast skill after the year 2000 , studies with a coupled ocean-atmosphere climate model, similar to $\mathrm{Li}$ et al. (2015), are necessary. In coupled model simulations that are forced with observed SST for the Atlantic and Indian Ocean, Li et al. (2015) have investigated observed changes in the mean tropical climate. Their study needs to be extended to the analysis of the evolution and predictability of EN and LN events with a focus on the statistical relationships identified in our study.

Acknowledgments. We would like to acknowledge data and technical assistance provided by Allan Clarke and Steve Van Gorder for the FSU model, David Unger for CPC CCA, Cecile Penland for CPC LIM, and Huug Van den Dool for CPC CA. CPC Markov data were provided by NOAA CPC (at http://www.cpc.ncep.noaa. gov/products/people/yxue/ENSO_forecast_clim71-00_ godas.html). NOAA CFS and NASA GMAO data were provided by the International Research Institute Data Library (at http://iridl.ldeo.columbia.edu/SOURCES/ .Models/.NMME/). Partial funding for this research was provided by the Engineering and Physical Sciences Research Council (EPSRC) as part of the Low Carbon Climate-Responsive Heating and Cooling of Cities (LoHCool) project (EP/N009797/1). Andy W.-C. Lai would also like to acknowledge the support from James Lai, Grace Chang, and Joey Cheng.

\section{REFERENCES}

Adams, J. B., M. E. Mann, and C. M. Ammann, 2003: Proxy evidence for an El Niño-like response to volcanic forcing. Nature, 426, 274-278, https://doi.org/10.1038/nature02101.

Ashok, K., S. K. Behera, S. A. Rao, H. Weng, and T. Yamagata, 2007: El Niño Modoki and its possible teleconnection. J. Geophys. Res., 112, C11007, https://doi.org/10.1029/2006JC003798.

Balmaseda, M., and D. Anderson, 2009: Impact of initialization strategies and observations on seasonal forecast skill. Geophys. Res. Lett., 36, L01701, https://doi.org/10.1029/2008GL035561.

Barnston, A. G., and C. F. Ropelewski, 1992: Prediction of ENSO episodes using canonical correlation analysis. J. Climate, 5, 
1316-1345, https://doi.org/10.1175/1520-0442(1992)005<1316: POEEUC $>2.0 . \mathrm{CO} ; 2$.

—- M. K. Tippett, M. L. L'Heureux, S. Li, and D. G. DeWitt, 2012: Skill of real-time seasonal ENSO model predictions during 2002-11: Is our capability increasing? Bull. Amer. Meteor. Soc., 93, 631-651, https://doi.org/10.1175/ BAMS-D-11-00111.1.

Behringer, D., and Y. Xue, 2004: Evaluation of the global ocean data assimilation system at NCEP: The Pacific Ocean. Eighth Symp. on Integrated Observing and Assimilation Systems for Atmosphere, Oceans, and Land Surface, Seattle, WA, Amer. Meteor. Soc., 2.3, https://ams.confex.com/ams/pdfpapers/ 70720.pdf.

Bjerknes, J., 1969: Atmospheric teleconnections from the equatorial Pacific. Mon. Wea. Rev., 97, 163-172, https://doi.org/ 10.1175/1520-0493(1969)097<0163:ATFTEP > 2.3.CO;2.

Bond, N. A., J. E. Overland, M. Spillane, and P. Stabeno, 2003: Recent shifts in the state of the North Pacific. Geophys. Res. Lett., 30, 2183, https://doi.org/10.1029/2003GL018597.

Bunge, L., and A. J. Clarke, 2014: On the warm water volume and its changing relationship with ENSO. J. Phys. Oceanogr., 44, 1372-1385, https://doi.org/10.1175/ JPO-D-13-062.1.

Burnham, K. P., and D. R. Anderson, 2002: Model Selection and Multimodel Inference: A Practical Information-Theoretic Approach. 2nd ed. Springer, 488 pp., https://doi.org/10.1007/ b97636.

Cai, W., and Coauthors, 2015: Increased frequency of extreme La Niña events under greenhouse warming. Nat. Climate Change, 5, 132-137, https://doi.org/10.1038/nclimate2492.

Chen, D., and Coauthors, 2015: Strong influence of westerly wind bursts on El Niño diversity. Nat. Geosci., 8, 339-345, https:// doi.org/10.1038/ngeo2399.

Chen, S., W. Chen, B. Yu, and H.-F. Graf, 2013: Modulation of the seasonal footprinting mechanism by the boreal spring Arctic Oscillation. Geophys. Res. Lett., 40, 6384-6389, https://doi.org/ 10.1002/2013GL058628.

Chen, X., and J. M. Wallace, 2015: ENSO-like variability: 19002013. J. Climate, 28, 9623-9641, https://doi.org/10.1175/ JCLI-D-15-0322.1.

Choi, J., S.-I. An, J.-S. Kug, and S.-W. Yeh, 2011: The role of mean state on changes in El Niño's flavor. Climate Dyn., 37, 12051215, https://doi.org/10.1007/s00382-010-0912-1.

Chung, P.-H., and T. Li, 2013: Interdecadal relationship between the mean state and El Niño types. J. Climate, 26, 361-379, https://doi.org/10.1175/JCLI-D-12-00106.1; Corrigendum, 26, 2700, https://doi.org/10.1175/JCLI-D-13-00112.1.

Clarke, A. J., and S. Van Gorder, 2003: Improving El Niño prediction using a space-time integration of Indo-Pacific winds and equatorial Pacific upper ocean heat content. Geophys. Res. Lett., 30, 1399, https://doi.org/10.1029/ 2002 GL016673.

Compo, G. P., and Coauthors, 2011: The Twentieth Century Reanalysis Project. Quart. J. Roy. Meteor. Soc., 137, 1-28, https:// doi.org/10.1002/qj.776.

Cravatte, S., T. Delcroix, D. Zhang, M. McPhaden, and J. Leloup, 2009: Observed freshening and warming of the western Pacific warm pool. Climate Dyn., 33, 565-589, https://doi.org/10.1007/ s00382-009-0526-7.

Dayan, H., J. Vialard, T. Izumo, and M. Lengaigne, 2014: Does sea surface temperature outside the tropical Pacific contribute to enhanced ENSO predictability? Climate Dyn., 43, 1311-1325, https://doi.org/10.1007/s00382-013-1946-y.
DelSole, T., and J. Shukla, 2009: Artificial skill due to predictor screening. J. Climate, 22, 331-345, https://doi.org/10.1175/ 2008JCLI2414.1.

DeMott, C. A., N. P. Klingaman, and S. J. Woolnough, 2015: Atmosphere-ocean coupled processes in the Madden-Julian oscillation. Rev. Geophys., 53, 1099-1154, https://doi.org/ 10.1002/2014RG000478.

Ding, H., N. S. Keenlyside, and M. Latif, 2012: Impact of the equatorial Atlantic on the El Niño Southern Oscillation. Climate Dyn., 38, 1965-1972, https://doi.org/10.1007/s00382-011-1097-y.

Dommenget, D., T. Bayr, and C. Frauen, 2013: Analysis of the nonlinearity in the pattern and time evolution of El Niño Southern Oscillation. Climate Dyn., 40, 2825-2847, https://doi.org/ 10.1007/s00382-012-1475-0.

Dong, B., R. T. Sutton, and A. A. Scaife, 2006: Multidecadal modulation of El Niño-Southern Oscillation (ENSO) variance by Atlantic Ocean sea surface temperatures. Geophys. Res. Lett., 33, L08705, https://doi.org/10.1029/ 2006 GL025766.

Eisenman, I., L. Yu, and E. Tziperman, 2005: Westerly wind bursts: ENSO's tail rather than the dog? J. Climate, 18, 5224-5238, https://doi.org/10.1175/JCLI3588.1.

England, M. H., and Coauthors, 2014: Recent intensification of wind-driven circulation in the Pacific and the ongoing warming hiatus. Nat. Climate Change, 4, 222-227, https://doi.org/ 10.1038/nclimate2106.

Fedorov, A. V., S. Hu, M. Lengaigne, and E. Guilyardi, 2015: The impact of westerly wind bursts and ocean initial state on the development, and diversity of El Niño events. Climate Dyn., 44, 1381-1401, https://doi.org/10.1007/s00382-014-2126-4.

Flügel, M., and P. Chang, 1998: Does the predictability of ENSO depend on the seasonal cycle? J. Atmos. Sci., 55, 3230-3243, https://doi.org/10.1175/1520-0469(1998)055<3230: DTPOED $>2.0 . \mathrm{CO} ; 2$

Frauen, C., and D. Dommenget, 2010: El Niño and La Niña amplitude asymmetry caused by atmospheric feedbacks. Geophys. Res. Lett., 37, L18801, https://doi.org/10.1029/ 2010GL044444; Corrigendum, 38, L02805, https://doi.org/ 10.1029/2010GL045541.

_ and - 2012: Influences of the tropical Indian and Atlantic Oceans on the predictability of ENSO. Geophys. Res. Lett., 39, L02706, https://doi.org/10.1029/2011GL050520.

Gebbie, G., and E. Tziperman, 2009: Predictability of SSTmodulated westerly wind bursts. J. Climate, 22, 3894-3909, https://doi.org/10.1175/2009JCLI2516.1.

Giese, B. S., and S. Ray, 2011: El Niño variability in simple ocean data assimilation (SODA), 1871-2008. J. Geophys. Res., 116, C02024, https://doi.org/10.1029/2010JC006695.

Goddard, L., S. J. Mason, S. E. Zebiak, C. F. Ropelewski, R. Basher, and M. A. Cane, 2001: Current approaches to seasonal to interannual climate predictions. Int. J. Climatol., 21, 1111-1152, https://doi.org/10.1002/joc.636.

Graf, H.-F., 1986: On the El-Niño/Southern Oscillation and Northern Hemispheric temperature. Gerlands Beitr. Geophys., 95, 63-75.

Ham, Y.-G., J.-S. Kug, J.-Y. Park, and F.-F. Jin, 2013a: Sea surface temperature in the north tropical Atlantic as a trigger for El Niño/Southern Oscillation events. Nat. Geosci., 6, 112-116, https://doi.org/10.1038/ngeo1686.

,$- \ldots$, and $-2013 \mathrm{~b}$ : Two distinct roles of Atlantic SSTs in ENSO variability: North tropical Atlantic SST and Atlantic Niño. Geophys. Res. Lett., 40, 4012-4017, https://doi.org/ 10.1002/grl.50729. 
Hartten, L. M., 1996: Synoptic settings of westerly wind bursts. J. Geophys. Res., 101, 16 997-17 019, https://doi.org/10.1029/ 96JD00030.

Hong, C.-C., Y.-K. Wu, T. Li, and C.-C. Chang, 2014: The climate regime shift over the Pacific during 1996/1997. Climate Dyn., 43, 435-446, https://doi.org/10.1007/s00382-013-1867-9.

Horii, T., I. Ueki, and K. Hanawa, 2012: Breakdown of ENSO predictors in the 2000s: Decadal changes of recharge/ discharge-SST phase relation and atmospheric intraseasonal forcing. Geophys. Res. Lett., 39, L10707, https:/doi.org/ 10.1029/2012GL051740.

Hu, S., A. V. Fedorov, M. Lengaigne, and E. Guilyardi, 2014: The impact of westerly wind bursts on the diversity and predictability of El Niño events: An ocean energetics perspective. Geophys. Res. Lett., 41, 4654-4663, https://doi.org/10.1002/ 2014GL059573.

Hu, Z.-Z., A. Kumar, H.-L. Ren, H. Wang, M. L'Heureux, and F.-F. Jin, 2013: Weakened interannual variability in the tropical Pacific Ocean since 2000. J. Climate, 26, 2601-2613, https://doi.org/ 10.1175/JCLI-D-12-00265.1.

Jin, E. K., and Coauthors, 2008: Current status of ENSO prediction skill in coupled ocean-atmosphere models. Climate Dyn., 31, 647-664, https://doi.org/10.1007/s00382-008-0397-3.

Jin, F.-F., 1997: An equatorial ocean recharge paradigm for ENSO. Part I : Conceptual model. J. Atmos. Sci., 54, 811-829, https:// doi.org/10.1175/1520-0469(1997)054<0811:AEORPF>2.0.CO;2.

Johnson, N. C., 2013: How many ENSO flavors can we distinguish? J. Climate, 26, 4816-4827, https://doi.org/10.1175/ JCLI-D-12-00649.1.

Kang, I.-S., and J.-S. Kug, 2002: El Niño and La Niña sea surface temperature anomalies: Asymmetry characteristics associated with their wind stress anomalies. J. Geophys. Res., 107, 4372, https://doi.org/10.1029/2001JD000393.

- , H.-H. No, and F. Kucharski, 2014: ENSO amplitude modulation associated with the mean SST changes in the tropical central Pacific induced by Atlantic multidecadal oscillation. J. Climate, 27, 7911-7920, https://doi.org/10.1175/ JCLI-D-14-00018.1.

Kao, H.-Y., and J.-Y. Yu, 2009: Contrasting eastern-Pacific and central-Pacific types of ENSO. J. Climate, 22, 615-632, https:// doi.org/10.1175/2008JCLI2309.1.

Keen, R. A., 1982: The role of cross-equatorial tropical cyclone pairs in the Southern Oscillation. Mon. Wea. Rev., 110, 1405-1416, https://doi.org/10.1175/1520-0493(1982)110<1405: TROCET $>2.0 . \mathrm{CO} ; 2$

Keenlyside, N. S., H. Ding, and M. Latif, 2013: Potential of equatorial Atlantic variability to enhance El Niño prediction. Geophys. Res. Lett., 40, 2278-2283, https://doi.org/10.1002/ grl.50362.

Kiladis, G. N., and H. F. Diaz, 1989: Global climate anomalies associated with extremes in the Southern Oscillation. J. Climate, 2, 1069-1090, https://doi.org/10.1175/1520-0442(1989)002<1069: GCAAWE $>2.0 . \mathrm{CO} ; 2$.

, G. A. Meehl, and K. M. Weickmann, 1994: Large-scale circulation associated with westerly wind bursts and deep convection over the western equatorial Pacific. J. Geophys. Res., 99, 18 527-18 544, https://doi.org/10.1029/94JD01486.

Krishnamurti, T. N., M. Kanamitsu, W. J. Koss, and J. D. Lee, 1973: Tropical east-west circulations during the northern winter. J. Atmos. Sci., 30, 780-787, https://doi.org/10.1175/ 1520-0469(1973)030<0780:TECDTN $>2.0 . C O ; 2$.

Kucharski, F., I.-S. Kang, R. Farneti, and L. Feudale, 2011: Tropical Pacific response to 20th century Atlantic warming.
Geophys. Res. Lett., 38, L03702, https://doi.org/10.1029/ 2010 GL046248.

_ , and Coauthors, 2016: Atlantic forcing of Pacific decadal variability. Climate Dyn., 46, 2337-2351, https://doi.org/ 10.1007/s00382-015-2705-z.

Kug, J.-S., F.-F. Jin, and S.-I. An, 2009: Two types of El Niño events: Cold tongue El Niño and warm pool El Niño. J. Climate, 22, 1499-1515, https://doi.org/10.1175/2008JCLI2624.1.

Lai, A. W.-C., M. Herzog, and H.-F. Graf, 2015: Two key parameters for the El Niño continuum: Zonal wind anomalies and western Pacific subsurface potential temperature. Climate Dyn., 45, 3461-3480, https://doi.org/10.1007/ s00382-015-2550-0.

Latif, M., T. P. Barnett, M. A. Cane, M. Flügel, N. E. Graham, H. von Storch, J.-S. Xu, and S. E. Zebiak, 1994: A review of ENSO prediction studies. Climate Dyn., 9, 167-179, https:// doi.org/10.1007/BF00208250.

Lee, T., and M. J. McPhaden, 2010: Increasing intensity of El Niño in the central-equatorial Pacific. Geophys. Res. Lett., 37, L14603, https://doi.org/10.1029/2010GL044007.

Levine, A. F. Z., M. J. McPhaden, and D. M. W. Frierson, 2017: The impact of the AMO on multidecadal ENSO variability. Geophys. Res. Lett., 44, 3877-3886, https://doi.org/10.1002/ 2017GL072524.

Li, J., B. Liu, J. Li, and J. Mao, 2015: A comparative study on the dominant factors responsible for the weaker-than-expected El Niño event in 2014. Adv. Atmos. Sci., 32, 1381-1390, https:// doi.org/10.1007/s00376-015-4269-6.

Li, X., S.-P. Xie, S. T. Gille, and C. Yoo, 2016: Atlantic-induced pan-tropical climate change over the past three decades. Nat. Climate Change, 6, 275-279, https://doi.org/10.1038/ nclimate2840.

Liu, P., and C.-H. Sui, 2014: An observational analysis of the oceanic and atmospheric structure of global-scale multi-decadal variability. Adv. Atmos. Sci., 31, 316-330, https://doi.org/ 10.1007/s00376-013-2305-y.

López-Parages, J., B. Rodríguez-Fonseca, D. Dommenget, and C. Frauen, 2016: ENSO influence on the North Atlantic European climate: A non-linear and non-stationary approach. Climate Dyn., 47, 2071-2084, https://doi.org/10.1007/ s00382-015-2951-0.

Luo, J.-J., W. Sasaki, and Y. Masumoto, 2012: Indian Ocean warming modulates Pacific climate change. Proc. Natl. Acad. Sci. USA, 109, 18701-18706, https://doi.org/10.1073/ pnas.1210239109.

Lyon, B., A. G. Barnston, and D. G. DeWitt, 2014: Tropical Pacific forcing of a 1998-1999 climate shift: Observational analysis and climate model results for the boreal spring season. Climate Dyn., 43, 893-909, https://doi.org/10.1007/ s00382-013-1891-9.

Marathe, S., K. Ashok, P. Swapna, and T. P. Sabin, 2015: Revisiting El Niño Modokis. Climate Dyn., 45, 3527-3545, https://doi.org/ 10.1007/s00382-015-2555-8.

Martín-Rey, M., B. Rodríguez-Fonseca, I. Polo, and F. Kucharski, 2014: On the Atlantic-Pacific Niños connection: A multidecadal modulated mode. Climate Dyn., 43, 3163-3178, https://doi.org/10.1007/s00382-014-2305-3.

,-- , and -2015 : Atlantic opportunities for ENSO prediction. Geophys. Res. Lett., 42, 6802-6810, https://doi.org/ 10.1002/2015GL065062.

McGregor, S., A. Timmermann, M. F. Stuecker, M. H. England, M. Merrifield, F.-F. Jin, and Y. Chikamoto, 2014: Recent Walker circulation strengthening and Pacific cooling amplified 
by Atlantic warming. Nat. Climate Change, 4, 888-892, https:// doi.org/10.1038/nclimate2330.

McPhaden, M. J., 2003: Tropical Pacific Ocean heat content variations and ENSO persistence barriers. Geophys. Res. Lett., 30, 1480, https://doi.org/10.1029/2003GL016872.

_- 2012: A 21st century shift in the relationship between ENSO SST and warm water volume anomalies. Geophys. Res. Lett., 39, L09706, https://doi.org/10.1029/ 2012 GL051826.

__ 2015: Playing hide and seek with El Niño. Nat. Climate Change, 5, 791-795, https://doi.org/10.1038/nclimate2775.

_ T. Lee, and D. McClurg, 2011: El Niño and its relationship to changing background conditions in the tropical Pacific Ocean. Geophys. Res. Lett., 38, L15709, https://doi.org/10.1029/ 2011 GL048275.

Meinen, C. S., and M. J. McPhaden, 2000: Observations of warm water volume changes in the equatorial Pacific and their relationship to El Niño and La Niña. J. Climate, 13, 3551-3559, https://doi.org/10.1175/1520-0442(2000)013<3551: OOWWVC $>2.0 . \mathrm{CO} ; 2$.

Menkes, C. E., M. Lengaigne, J. Vialard, M. Puy, P. Marchesiello, S. Cravatte, and G. Cambon, 2014: About the role of westerly wind events in the possible development of an El Niño in 2014. Geophys. Res. Lett., 41, 6476-6483, https://doi.org/10.1002/ 2014 GL061186.

Minobe, S., 2000: Spatio-temporal structure of the pentadecadal variability over the North Pacific. Prog. Oceanogr., 47, 381408, https://doi.org/10.1016/S0079-6611(00)00042-2.

Newman, M., M. A. Alexander, and J. D. Scott, 2011: An empirical model of tropical ocean dynamics. Climate Dyn., 37, 18231841, https://doi.org/10.1007/s00382-011-1034-0.

Paek, H., J.-Y. Yu, and C. Qian, 2017: Why were the 2015/16 and 1997/98 extreme El Niños different? Geophys. Res. Lett., 44, 1848-1856, https://doi.org/10.1002/2016GL071515.

Pascolini-Campbell, M., D. Zanchettin, O. Bothe, C. Timmreck, D. Matei, J. H. Jungclaus, and H.-F. Graf, 2015: Toward a record of central Pacific El Niño events since 1880. Theor. Appl. Climatol., 119, 379-389, https://10.1007/s00704-014-1114-2.

Penland, C., and T. Magorian, 1993: Prediction of Niño 3 sea surface temperatures using linear inverse modeling. J. Climate, $\mathbf{6}$, 1067-1076, https://doi.org/10.1175/1520-0442(1993)006<1067: PONSST $>2.0 . \mathrm{CO} ; 2$.

Philander, S. G. H., T. Yamagata, and R. C. Pacanowski, 1984: Unstable air-sea interactions in the tropics. J. Atmos. Sci., 41, 604-613, https://doi.org/10.1175/1520-0469(1984)041<0604: UASIIT $>2.0 . \mathrm{CO} ; 2$.

Polo, I., M. Martín-Rey, B. Rodríguez-Fonseca, F. Kucharski, and C. R. Mechoso, 2015: Processes in the Pacific La Niña onset triggered by the Atlantic Niño. Climate Dyn., 44, 115-131, https://doi.org/10.1007/s00382-014-2354-7.

Puy, M., J. Vialard, M. Lengaigne, and E. Guilyardi, 2016: Modulation of equatorial Pacific westerly/easterly wind events by the Madden-Julian oscillation and convectively-coupled Rossby waves. Climate Dyn., 46, 2155-2178, https://doi.org/ 10.1007/s00382-015-2695-x.

Rao, S. A., A. R. Dhakate, S. K. Saha, S. Mahapatra, H. S. Chaudhari, S. Pokhrel, and S. K. Sahu, 2012: Why is Indian Ocean warming consistently? Climatic Change, 110, 709-719, https://doi.org/10.1007/s10584-011-0121-x.

Reynolds, R. W., N. A. Rayner, T. M. Smith, D. C. Stokes, and W. Wang, 2002: An improved in situ and satellite SST analysis for climate. J. Climate, 15, 1609-1625, https://doi.org/10.1175/ 1520-0442(2002)015<1609:AIISAS>2.0.CO;2.
Rodríguez-Fonseca, B., I. Polo, J. García-Serrano, T. Losada, E. Mohino, C. R. Mechoso, and F. Kucharski, 2009: Are Atlantic Niños enhancing Pacific ENSO events in recent decades? Geophys. Res. Lett., 36, L20705, https://doi.org/ 10.1029/2009GL040048.

Ropelewski, C. F., and M. S. Halpert, 1987: Global and regional scale precipitation patterns associated with the El Niño/Southern Oscillation. Mon. Wea. Rev., 115, 1606-1626, https://doi.org/10.1175/ 1520-0493(1987)115<1606:GARSPP>2.0.CO;2.

Saha, S., and Coauthors, 2014: The NCEP Climate Forecast System version 2. J. Climate, 27, 2185-2208, https://doi.org/10.1175/ JCLI-D-12-00823.1.

Sohn, B. J., S.-W. Yeh, J. Schmetz, and H.-J. Song, 2013: Observational evidences of Walker circulation change over the last 30 years contrasting with GCM results. Climate Dyn., 40, 1721-1732, https://doi.org/10.1007/ s00382-012-1484-z.

Stevenson, S., B. Otto-Bliesner, J. Fasullo, and E. Brady, 2016: "El Niño like" hydroclimate response to last millennium volcanic eruptions. J. Climate, 29, 2907-2921, https://doi.org/10.1175/ JCLI-D-15-0239.1.

Su, J., T. Li, and R. Zhang, 2014: The initiation and developing mechanisms of central Pacific El Niños. J. Climate, 27, 44734485, https://doi.org/10.1175/JCLI-D-13-00640.1.

Suarez, M. J., and P. S. Schopf, 1988: A delayed action oscillator for ENSO. J. Atmos. Sci., 45, 3283-3287, https://doi.org/10.1175/ 1520-0469(1988)045<3283:ADAOFE > 2.0.CO;2.

Suárez-Moreno, R., and B. Rodríguez-Fonseca, 2015: S ${ }^{4}$ CAST v2.0: Sea surface temperature based statistical seasonal forecast model. Geosci. Model Dev., 8, 3639-3658, https://doi.org/ 10.5194/gmd-8-3639-2015.

Timmermann, A., and Coauthors, 2007: The influence of a weakening of the Atlantic meridional overturning circulation on ENSO. J. Climate, 20, 4899-4919, https://doi.org/10.1175/ JCLI4283.1.

Torrence, C., and P. J. Webster, 1998: The annual cycle of persistence in the El Niño/Southern Oscillation. Quart. J. Roy. Meteor. Soc., 124, 1985-2004, https://doi.org/10.1002/ qj.49712455010.

Van den Dool, H. M., 1994: Searching for analogues, how long must we wait? Tellus, 46A, 314-324, https://doi.org/10.1034/ j.1600-0870.1994.t01-2-00006.x.

Wang, L., J.-Y. Yu, and H. Paek, 2017: Enhanced biennial variability in the Pacific due to Atlantic capacitor effect. Nat. Commun., 8, 14887, https://doi.org/10.1038/ncomms14887.

Wen, C., A. Kumar, Y. Xue, and M. J. McPhaden, 2014: Changes in tropical Pacific thermocline depth and their relationship to ENSO after 1999. J. Climate, 27, 7230-7249, https://doi.org/ 10.1175/JCLI-D-13-00518.1.

Wyrtki, K., 1975: El Niño-The dynamic response of the equatorial Pacific Ocean to atmospheric forcing. J. Phys. Oceanogr., 5, 572-584, https://doi.org/10.1175/1520-0485(1975)005<0572: ENTDRO $>2.0 . \mathrm{CO} ; 2$.

Xiang, B., B. Wang, and T. Li, 2013: A new paradigm for the predominance of standing central Pacific warming after the late 1990s. Climate Dyn., 41, 327-340, https://doi.org/10.1007/ s00382-012-1427-8.

Xue, Y., M. A. Cane, S. E. Zebiak, and M. B. Blumenthal, 1994: On the prediction of ENSO: A study with a low-order Markov model. Tellus, 46A, 512-528, https://doi.org/10.3402/ tellusa.v46i4.15641

Yeh, S.-W., J.-S. Kug, and S.-I. An, 2014: Recent progress on two types of El Niño: Observations, dynamics, and future changes. 
Asia-Pac. J. Atmos. Sci., 50, 69-81, https://doi.org/10.1007/ s13143-014-0028-3.

Yu, J.-Y., and S. T. Kim, 2010: Three evolution patterns of CentralPacific El Niño. Geophys. Res. Lett., 37, L08706, https:// doi.org/10.1029/2010GL042810.

$\mathrm{Yu}, \mathrm{L}$. , and M. M. Rienecker, 1998: Evidence of an extratropical atmospheric influence during the onset of the 1997-98 El Niño. Geophys. Res. Lett., 25, 3537-3540, https://doi.org/ 10.1029/98GL02628.

Zanchettin, D., O. Bothe, H. F. Graf, N.-E. Omrani, A. Rubino, and J. H. Jungclaus, 2016: A decadally delayed response of the tropical Pacific to Atlantic multidecadal variability. Geophys. Res. Lett., 43, 784-792, https://doi.org/10.1002/ 2015 GL067284.

Zhang, L., and K. B. Karnauskas, 2017: The role of tropical interbasin SST gradients in forcing Walker circulation trends. J. Climate, 30, 499-508, https://doi.org/10.1175/ JCLI-D-16-0349.1.

Zhang, R., and T. L. Delworth, 2005: Simulated tropical response to a substantial weakening of the Atlantic thermohaline circulation. J. Climate, 18, 1853-1860, https://doi.org/10.1175/ JCLI3460.1. 